\title{
ANALYSIS OF THE AGRICULTURAL SECTOR GROWTH USING MALMQUIST TOTAL FACTOR PRODUCTIVITY INDEX FOR 165 COUNTRIES
}

\author{
Ayman M. Abouzeid \\ Agricultural Economics Department, Faculty of Agricultural, Menofia University, Shebeen \\ El-Koam, Egypt
}

Keywords: Distance function, Technical efficiency change, technical change, Malmquist, Total Factor Productivity, Data envelopment analysis.

\section{ABSTRACT}

This study was conducted to estimates the Malmquist productivity indices using the data envelopment analysis (DEA) for 165 countries over 8 regions and classified across 8 groups based on agricultural gross production value during the study period (1980-2007). The total factor productivity including and measure the efforts in the resource allocation, modernization, the technological change, and catch-up efforts in the agriculture sector in any country. While, Malmquist TFP index measures total factor productivity change between two data points by calculating the ratio of the distance function of each data point relative to a common technology. The data used in this study was drawn from the Food and Agriculture Organization of the United Nations. This paper also estimated the technical efficiency, technical efficiency change and technical change for countries in each group and for all those countries as one group.

\section{INTRODUCTION}

In the last six decades, productivity growth in agriculture has been considered the essential interest of the agricultural economists due to the increase of the demand for food and raw materials out of the agricultural sector output. The development economists conducted many researches to study the sources of productivity growth of the cross-countries differences over specific periods.
The economical studies in the productivity and development that had pioneer role in investigating the sources of productivity growth in different countries are conducted by Hayami \& Ruttan (1970, 1971); Kawagoe \& Hayami (1983, 1985); Kawagoe et al (1985); Capalbo \& Antle (1988) and Lau \& Yotopoulos (1989). Most researches in this field focused firstly on the study of the total factor productivity (Abramovitz (1962); Nadiri (1970); Solow (1957); Ruttan (1960) and Griliches (1963). The studies conducted later focus more on productivity decomposition (Afriat, 1972, Caves, 1993), Fare, 1994, Fare, 1995, Fare, 1997, Arnade, 1998 and Coelli, 1998).

While Shephard (1953) introduced the input distance function in the context of production analysis, Malmquist (1953) introduced the input distance function in the context of consumption analysis and developed a standard of living index as a ratio of pair of the input distance function. In the context of production analysis, Malmquist standard of living index becomes an input quantity index. There is an analogous output quantity index based on output function introduced by Shepherd (1970). Two approaches have been developed: The first approach is partially oriented, being based either on, a) a ratio of output distance function or b) a ratio of input distance function; this approach was pioneered by Caves et al (1982) and called Malmquist productivity index.The second approach is simultaneously oriented, being based on a ratio of output distance function contained in the output quantity index and the ratio of input distance function contained in the input quantity index; this approach is called Malmquist total factor productivity index. 
The information revolution that hit all life aspects had an essential role in developing new economical methodologies and allowed more data sets that helped in estimating productivity decomposition in the most recent studies rather than using the old techniques applied with total factor productivity. In the last three decades, the productivity growth measurement literature has been extended from the standard calculations TFP employing production function towards more refined decomposition methods. These techniques, which are based on the Decomposition of TFP index, have been developed that are. Malmquist method becomes the most common approach to measure the productivity growth. Caves, Christensen and Diewert (1982) developed non-parametric perspective to measure the output produced per unit of input. However, Fare et al (1994) developed the output distance function method of Shepherd (1970).

The studies in the area of growth productivity in agriculture have been conducted for several countries and regions over time courses using different common economical techniques such as CobbDouglas production function (Fulginiti \& Perrin, 1993, Craig et al 1997, Wiebe et al 2000 and Fulginiti \& Perrin, 1998). Data Envelopment Analysis (Fulginiti \& Perrin, 1997), Lusigi \& Thirtle, 1997, Rao \& Coelli, 1998, Arnade, 1998, Chavas, 2001, Suhariyanto et al 2001, Suhariyanto \& Thirtle, 2001, Trueblood \& Coggins, 2003, Nin et al 2003 and Coelli et al 2005, Fisher Index and other techniques. (Bureau et al 1995 and Ball et al 2001).

\section{MATERIAL AND METHODS}

\section{Research problem}

Many of the growth studies in the agricultural sector were conducted to estimate and decompose the total factor productivity index using several methods such as Data Envelopment Analysis. However, most of these studies had some problems in the estimation of this index which led to give unprecise results. The majority of these studies that estimated the TFA index included all the countries of their studies as a one group regardless the big difference between them in the agricultural production values, stock of technology and technical efficiency. Moreover, most of these studies didn't include the capital stock data as a production input in their consideration to estimate the TFA index. Therefore, the current study aims to estimate the TFA index with new prospective to overcome the previous hurdles.

\section{Research objective}

The aim of this study is to estimate and decompose the total factor productivity (technical efficiency change - technical change - scale efficiency change) during the period (1980-2007) for countries in each group and for all countries as one group.

\section{Methodology}

As noted by Kumar (2006) and Collie (2003), the total factor productivity (TFP) estimation are based on average production function and growth accounting methodology. They assume that a firm is operating on its production frontier, TFP is treated analogous to technical change. This approach use several restrictive assumptions such as Constant return to scale, and Allocative and technical efficiency have to be made. However, some papers use nonparametric linear programming technique to construct the Malmquist productivity index. The Malmquist productivity index was introduced as a theoretical index by Caves et al (1982) and popularized as an empirical index by Fare et al (1994), the Malmquist index has several features:

1- It is a TFP index

2- It can be constructed using distance function, which primal measure based only on input and output quantity rather than prices.

3- The index can be decomposed into technical efficiency change, technical change, and scale component.

These studies use Linear programming as an approach to construct the Malmquist productivity index. This approach has two advantage over the econometrics one in measuring productivity change:

1- It compares the country to the best practice technology rather than average practice technology as it is done by econometrics studies.

2- It dose not require the specification of an ad hoc function form or error structure.

3- The LP approach allows recovery of various efficiency and productivity measures in an easily calculable measure. It is able to answer question related to technical efficiency, scale efficiency and productivity change. 
Malmquist TFP index measures total factor productivity change between two data points by calculating the ratio of the distance function of each data point relative to a common technology. The Malmquist is defined using distance function, which describes a multi-input multi-output production technology without the need to specify a behavioral objectives. Input distance function characterize the production technology by looking at minimal proportional contraction of the output vector given an output vector.

Output distance function considers a maximal proportional expansion of the output vector, given an input vector. Production technology may be defined using the output set, $p(x)$, which represents the set of all output vector $(y)$, which can be produced using the input vector $(\mathrm{x})$.

$$
P(x)=\{y: x \text { can produce } y\}
$$

The input distance function is defined on the output set $P(x)$ as:

$$
D_{o}(x, y)=\min \{\delta:(y / x) \in P(x)\}
$$

The distance function will take value that:

1- Is less or equal to one if the output $(y)$ is an element of the feasible production set $P(x)$.

2- A value of unity if the output $(y)$ is located on the outer boundary of the feasible production set $P(x)$

3- A greater than one if $y$ is located outside the feasible production set $P(x)$.

DEA like method are used to calculate the distance measure and Malmquist TFP index measures the TFP change between two data points by calculating the: Raito of the distance function of each data point relative to a common technology. Following Coelli et al (2005), the required distance measure for the Malmquist TFP index are calculating using DEA like liner programming For the ith country four distance functions are calculated in order to measure the TFP change between two period $t, t+1$, This requires the solving of four liner programming LP problems.

Fare et al (1994) assume a constant return to scale (CRS) technology. This very important in TFP measurement, A CRS technology used in this study for two reasons

1- Given that the analysis involve the use of aggregate country level data.

2- Is applicable to both firm level and aggregate data.

\section{Measure the change in output oriented}

Table (5) shows that how to create the output distance function between two points data and two technology to calculate the output Malmquist TFP index. The output Malmquist TFP change between two data points is estimated by calculating the ratio of distance of each data point relative to a common technology. Following Fare et al (1994), Malmquist TFP change index (output-oriented) between period $(t)$ and period $(t+1)$ is shows in Table (5) given by :

Malmquist output index or total factor productivity $=$

$$
\left[\frac{D_{o}^{t+1}\left(y^{t+1}, x^{t+1}\right)}{D_{o}^{t+1}\left(y^{t}, x^{t}\right)} * \frac{D_{o}^{t}\left(y^{t+1}, x^{t+1}\right)}{D_{o}^{t}\left(y^{t}, x^{t}\right)}\right]^{0.5}
$$

The equation is geometric mean of two TFP indices:

1- Is evaluated with respect to period (t) technology

2- Is evaluated with respect to period $(t+1)$ technology

If Malmquist output index or total factor productivity (MALM) is

- More than (1): it indicates positive TFP growth from period $(t)$ to period $(t+1)$.

- Less than (1) : it indicates TFP decline from period $(t)$ to period $(t+1)$.

- Equal (1) : it indicates TFP have no change from period $(\mathrm{t})$ to period $(\mathrm{t}+1$.)

Malmaquist Total factor Productivity Index =

$M A L M=\left[\frac{D f 4}{D f 2} * \frac{D f 3}{D f 1}\right]^{0.5}$

Multiplier equation (1) by $\frac{D f 4}{D f 4} * \frac{D f 1}{D f 1}$

$M A L M=\left[\frac{D f 4}{D f 2} * \frac{D f 3}{D f 1}\right]^{0.5}=$

$M A L M=\left[\frac{D f 4}{D f 1} * \frac{D f 4}{D f 1} * \frac{D f 3}{D f 4} * \frac{D f 1}{D f 2}\right]^{0.5}=\left[\left(\frac{D f 4}{D f 1}\right)^{2} * \frac{D f 3}{D f 4} *\right.$

$\left.\frac{D f 1}{D f 2}\right]^{0.5}$

Malmquist indexMALM $=\frac{D f 4}{D f 1} *\left[\frac{D f 1}{D f 2} * \frac{D f 3}{D f 4}\right]^{0.5} \ldots . .(4)$

Technical efficiency change $\left(T_{\text {ef.ch. }}\right)$ is equivalent to the ratio of the Technical efficiency $\left(T_{\text {ef }}\right)$ in period $(t+1)$ to the Technical efficiency. in period (t) and the Geometric mean of the shift in technology between the two periods evaluated at $X_{t+1}, X_{t}$. Technical efficiency change $\left(T_{\text {ef.ch. }}\right)=\frac{D f 4}{D f 1}$

Following Kumar (2006), and Collie (2003):

$$
T_{\text {ef.ch. }}=
$$

Pure Technical efficiency change $\left(P T_{\text {ef.ch. }}\right) *$

Input Scale efficiency $\left(S_{\text {ef.ch. }}\right) \ldots \ldots \ldots \ldots \ldots \ldots \ldots$

Technical Change $\left(T_{c h .}\right)=\left[\frac{D f 1}{D f 2} * \frac{D f 3}{D f 4}\right]^{0.5}$

From equation (5), equation (7)

$M L M A=T_{\text {ef.ch. }} * T_{\text {ch }}$

from equation (6)

$M L M A=P T_{\text {ef.ch. }} * S_{\text {ef.ch. }} * T_{\text {ch }}$ 
This paper uses the Malmquist index method to measure total factor productivity growth depend on Data Envelopment Analysis (DEA) to construct a piece-wise linear production for each year. As noted by Collie et al. (2005) DEA is a liner programming method, which uses data on the input and output of the countries under study to construct a piece -wise liner surface over the data points. The distance between the observed data point and the frontier refer to the degree of technical inefficiency of each country.

Data: the present study use the data which drawn from the faostat system of the statistics division of the Food and agricultural Organization in Rome and the statistics division of the world bank.

Output: Gross Production value constant million international dollar base year 2005.

The value of gross production has been compiled by multiplying gross production in physical terms by output prices at farm gate. Thus, value of production measures production in monetary terms at the farm gate level. Since intermediate uses within the agricultural sector (seed and feed) have not been subtracted from production data, the value of production aggregate refers to the notion of "gross production". The value of gross production is provided in constant terms and is expressed in international dollar ${ }^{1}$ Value of production in constant.

\section{Input: Labor in agriculture}

Economically active population in agriculture (agricultural labor force) is that part of the economically active population engaged in or seeking work in agriculture, hunting, fishing or forestry. This variable refers to the economically active population in

\footnotetext{
As noted by FAO Organization: International Dollar prices are international prices expressed in a common currency that were developed within the framework of GDP international comparisons. The Geary -Khamis international average price are based on prices ( in national currency units) and quantities of 185 agriculture commodities in 103 countries. International prices are useful in computing comparable value aggregates for different commodities groups. International prices are a function of production of the different commodities in different countries, of their national prices and of the exchange rates between national currencies. The Geary-Khamis approach that has been chosen by the UN to define the international prices and exchange rates derived from the data through a system of interdependent equations. In the equation system international prices of commodities are weighted averages of national prices converted into a common currency and weighted by national outputs. Exchange rates are equal to the ratio of the value of production of a given country at international prices divided by the value of production of the same country in national currency.
}

agriculture. This population is defined as all persons engaged or seeking employment in an economic activity, whether as employers' own-account workers, salaried employees, or unpaid workers, assisting in the operation of a family farm or business. The economically active population in agriculture includes all economically active people engaged in agriculture, forestry, hunting or fishing; this variable obviously overstates the labor input used in agriculture production.

\section{Gross capital stock (constant million USA dol- lar base year 2005)}

The estimate of capital stock in agriculture refers to a value that is attached to the total physical capital capacity available for repeated use in the production of other goods, in existence at specific point in time in the economy of agriculture sector. The estimates of investment in agriculture have indirectly been derived by the FAO Statistics Division using physical data on livestock, tractors, irrigated land and land under permanent crops, and the average prices for the year 1995. These data enabled the derivation of the capital stock in agriculture which is the gross, and the annual change in the latter is taken to reflect investment in agriculture. The FAO Statistics Division has compiled an updated dataset series of capital stock in Agriculture from 1975-2007 using 2005 constant prices as the base year. The dataset on capital stock in agriculture is important for analyzing a number of policy issues related to sustainable growth of agriculture and achieving food security. The dataset has been developed by multiplying unit prices by the quantity of physical assets in use compiled from individual countries.

\section{Time period, Region and Countries}

The study use data for the period 1980 to 2007 for 165 countries, Table (1) shows that the agricultural gross production value(Q), labor (L) and capital $(\mathrm{K})$ for these countries, which account for $91 \%$, $96 \%$, and $88 \%$ of the world's agricultural gross production value; world's agricultural labor; and world's stock capital respectively.

Table (1) shows that the 165 countries are classified on 8 groups based on agricultural gross production value in contestant million international dollars basis year 2005. For instance, Table (1) shows that there are 33 countries in group (1); the agricultural gross production value for each country on group (1) is less than (I\$ 100 million). 
Table 1. The annual average and percentage of Agricultural gross production value (Q), labor (L) and gross capital stock (K) for groups under study during (1980-2007).

\begin{tabular}{|ccccccccc|}
\hline Groups & Sets & Countries & $\begin{array}{c}\text { Q } \\
\text { (million I\$) }\end{array}$ & $\%$ & million worker & $\%$ & (USD million) & $\%$ \\
\hline Group 1 & Less than 100 & 33 & 1082 & 0.07 & 1.4 & 0.12 & 5585 & 0.11 \\
Group 2 & $100-500$ & 25 & 5893 & 0.36 & 7.0 & 0.61 & 23507 & 0.47 \\
Group 3 & $500-1000$ & 16 & 12833 & 0.79 & 17.4 & 1.50 & 67745 & 1.35 \\
Group 4 & $1000-2000$ & 20 & 28970 & 1.79 & 44.2 & 3.81 & 110713 & 2.20 \\
Group 5 & $2000-4000$ & 21 & 60654 & 3.75 & 49.3 & 4.25 & 274460 & 5.46 \\
Group 6 & $4000-8000$ & 16 & 78601 & 4.86 & 48.0 & 4.14 & 285389 & 5.67 \\
Group 7 & $8000-16000$ & 13 & 139030 & 8.59 & 100.9 & 8.70 & 478580 & 9.51 \\
Group 8 & More than 16000 & 21 & 1143315 & 70.64 & 845.5 & 72.90 & 3183339 & 63.27 \\
\hline total & 165 & 165 & 1470378 & 90.85 & 1113.7 & 96.02 & 4429319 & 88.04 \\
\hline World & & & 1618413 & 100 & 1159.9 & 100 & 5031076 & 100 \\
\hline
\end{tabular}

Source: selected and calculated from FAO (food and agricultural organization), faostat website

Similarly the total agricultural gross production value for those countries in group (1) is estimated to be around (I\$ 1.08) billion annually on average which posted the lowest groups of $0.07 \%$ of the world's agricultural gross production value during the study period. In addition, those countries on group (1) had $0.12 \%$ and $0.11 \%$ of world's agricultural labor and world's stock capital respectively on average. On the other hand, Table (1) shows that there are 21 countries in group (8), and the agricultural gross production value for each country is more than (I\$ 16 billion). The total agricultural gross production value for those countries in group (8) is (I\$ 1143) billion annually on average which posted the highest group of $70.6 \%$ of the world's agricultural gross production value during the study period. Also those countries on group (8) had $72.9 \%$ and $63.3 \%$ of world's agricultural labor and world's stock capital respectively on average during 1980-2007.

Table (2) shows that 165 countries distributed on 8 regions. For instance, there are 37 countries located in Asia. On the other hand, the total agricultural gross production value for these countries is ( $\$$ \$ 677) billion annually on average, which posted the highest region of $42 \%$ of the world's agricultural gross production value during the study period. These Asian countries understudy posted of $78 \%$ and $35 \%$ of world's agricultural labor and world's stock capital respectively on average. While the total agricultural gross production value for 22 countries located in Europe was $1 \$ 252$ billion on average which posted of $15.5 \%$ of the world's agricultural gross production, those coun- tries under study over Europe region posted of $1.6 \%$ and $14 \%$ of world's agricultural labor and world's stock capital respectively on average during the study period.

Table (2) shows that there are 53 countries over Africa region; the total agricultural gross production value for those countries is $1 \$ 115$ billion on average, which posted of $7.1 \%$ of the world's agricultural gross production. In addition, those countries posted of $11.7 \%$ and $7.8 \%$ of world's agricultural labor and world's stock capital respectively on average during the study period.

Table (2) includes 17 countries located in American Caribbean. As well as, the total agricultural gross production value for these countries was (I\$ 7.8) billion annually on average which posted the lowest region of $0.49 \%$ of the world's agricultural gross production value during the study period, However those countries under study located in Asia posted of $0.36 \%$ and $0.88 \%$ of world's agricultural labor, and world's stock capital respectively.

According to Table (2) there are only two countries under study in North America. The total agricultural gross production value for those countries was (I\$ 213) billion annually on average which posted of $13.2 \%$ of the world's agricultural gross production value during the study period. These two countries in North America posted of $0.34 \%$ and $14.1 \%$ of world's agricultural labor and world's stock capital respectively on average.

Table (3) shows that 165 countries are distributed on 8 regions and 8 groups in the same time, while, Table (4) shows that the agricultural gross 
Table 2. The annual average and percentage of Agricultural gross production value (Q), labor (L) and gross capital stock (K) for regions under study during (1980-2007).

\begin{tabular}{|cccccccc|}
\hline & \multicolumn{2}{c}{$\mathrm{Q}$} & \multicolumn{2}{c|}{$\mathrm{L}$} & \multicolumn{1}{c|}{$\mathrm{K}$} \\
\cline { 2 - 8 } & countries & (million I\$) & $\%$ & million workers & $\%$ & (USD million) & $\%$ \\
\hline Asia & 37 & 676684 & 41.81 & 907.7 & 78.26 & 1776661 & 35.31 \\
Africa & 53 & 115055 & 7.11 & 136.2 & 11.74 & 392236 & 7.80 \\
Europe & 22 & 251633 & 15.55 & 18.7 & 1.61 & 710314 & 14.12 \\
North America & 2 & 213111 & 13.17 & 3.9 & 0.34 & 710364 & 14.12 \\
South America & 13 & 140675 & 8.69 & 27.2 & 2.34 & 479886 & 9.54 \\
American Caribbean & 17 & 7893 & 0.49 & 4.2 & 0.36 & 44220 & 0.88 \\
Central America & 8 & 34118 & 2.11 & 13.4 & 1.15 & 138640 & 2.76 \\
Oceania & 13 & 31208 & 1.93 & 2.5 & 0.22 & 176997 & 3.52 \\
\hline total & 165 & 1470378 & 90.85 & 1113.7 & 96.02 & 4429319 & 88.04 \\
\hline World & & 1618413 & 100 & 1159.9 & 100 & 5031076 & 100 \\
\hline
\end{tabular}

Source : selected and calculated from FAO (food and agricultural organization), faostat website

Table 3. Distributed 165 countries under study over regions and groups during (1980-2007).

\begin{tabular}{|crrrrrrrrrrr|}
\hline Regions/groups & Groups & Groups & Groups & Groups & Groups & Groups & Groups & Groups \\
& 1 & 2 & 3 & 4 & 5 & 6 & 7 & 8 & total \\
\hline Asia & 3 & 6 & 4 & 2 & 7 & 1 & 6 & 8 & 37 \\
Africa & 8 & 12 & 6 & 12 & 6 & 6 & 2 & 1 & 53 \\
Europe & 2 & & 1 & 1 & 4 & 5 & 3 & 6 & 22 \\
North America & & & & & & & & 2 & 2 \\
South America & 1 & 2 & & 1 & 2 & 4 & 1 & 2 & 13 \\
American Caribbean & 10 & 3 & 2 & 1 & 1 & & & & 17 \\
Central America & & 1 & 3 & 2 & 1 & & & 1 & 8 \\
Oceania & 9 & 1 & & 1 & & & 1 & 1 & 13 \\
\hline Total & 33 & 25 & 16 & 20 & 21 & 16 & 13 & 21 & 165 \\
\hline
\end{tabular}

production value, agricultural labor and stock capital on average over 8 regions and 8 groups in the same time. For instance, Table (3) shows that there are 37 countries over Asia distributed in 8 groups. There are (3), (6), and group (4) countries in groups (1), (2) and (3) respectively. On the other hand, Table (4) shows that the agricultural gross production value for countries, which located in Asia and distributed in group (1), (2) and 3 is $1 \$ 60$, 1416, and 3237 million, respectively.

\section{RESULT AND DISCUSSION}

This part of study presents the results of the Malmquist productivity indices for 165 countries, countries are distributed over 8 regions. Those countries also divided into 8 groups based on an- nual average of agricultural gross value during the period 1980-2007. This paper attempts to estimate the Malmquist productivity indices for countries in each group separately, and for all 165 countries as one group. The results will be presented in two sections, First: The results depend on estimation for countries in each group, Second: the results depend on estimation for all countries as one group.

\section{1- The results depend on estimation for coun-} tries in each group.

a. Results for groups :

1- Technical efficiency

Table (6) shows the mean of the technical efficiency for each group during 1980-2007. 
Table 4. The annual average and percentage of Agricultural gross production value (Q), labor and gross capital stock for countries distrusted by region and groups during (1980-2007).

\begin{tabular}{|c|c|c|c|c|c|c|c|c|c|c|}
\hline regions & Items / groups & $g 1$ & g2 & g3 & $g 4$ & g5 & g6 & g7 & g8 & total \\
\hline \multirow[t]{6}{*}{ Asia } & $\mathrm{Q}$ (million I\$) & 60 & 1416 & 3237 & 2591 & 18487 & 4699 & 67001 & 579194 & 676684 \\
\hline & $\%$ world & 0 & 0.1 & 0.2 & 0.2 & 1.1 & 0.3 & 4.1 & 35.8 & 41.8 \\
\hline & Labor (million man) & 0.03 & 0.8 & 3.6 & 3.5 & 19.7 & 1 & 85.7 & 793.4 & 907.7 \\
\hline & $\%$ & 0 & 0.1 & 0.3 & 0.3 & 1.7 & 0.1 & 7.4 & 68.4 & 78.3 \\
\hline & Capital (million \$) & 215 & 4974 & 20226 & 6991 & 100644 & 18279 & 170894 & 1454439 & 1776661 \\
\hline & $\%$ & 0 & 0.1 & 0.4 & 0.1 & 2 & 0.4 & 3.4 & 28.9 & 35.3 \\
\hline \multirow[t]{6}{*}{ Africa } & $\mathrm{Q}$ (million I\$) & 291 & 3109 & 4772 & 16088 & 18442 & 28096 & 22702 & 21555 & 115055 \\
\hline & $\%$ world & 0 & 0.2 & 0.3 & 1 & 1.1 & 1.7 & 1.4 & 1.3 & 7.1 \\
\hline & Labor (million man) & 1 & 4.2 & 9.6 & 36.1 & 25.1 & 39.5 & 8.1 & 12.6 & 136.2 \\
\hline & $\%$ & 0.1 & 0.4 & 0.8 & 3.1 & 2.2 & 3.4 & 0.7 & 1.1 & 11.7 \\
\hline & Capital (million \$) & 1587 & 14275 & 24873 & 69640 & 55227 & 107792 & 73715 & 45127 & 392236 \\
\hline & $\%$ & 0 & 0.3 & 0.5 & 1.4 & 1.1 & 2.1 & 1.5 & 0.9 & 7.8 \\
\hline \multirow[t]{6}{*}{ Europe } & $\mathrm{Q}$ (million I\$) & 164 & & 809 & 1461 & 12436 & 27136 & 31237 & 178390 & 251633 \\
\hline & $\%$ world & 0.0 & & 0.0 & 0.1 & 0.8 & 1.7 & 1.9 & 11 & 15.5 \\
\hline & Labor (million man) & 0 & & 0.7 & 0.1 & 1.4 & 1.7 & 3.6 & 11.2 & 18.7 \\
\hline & $\%$ & 0 & & 0.1 & 0 & 0.1 & 0.1 & 0.3 & 1 & 1.6 \\
\hline & Capital (million \$) & 1112 & & 5371 & 9630 & 54791 & 72313 & 80104 & 486994 & 710314 \\
\hline & $\%$ & 0 & & 0.1 & 0.2 & 1.1 & 1.4 & 1.6 & 9.7 & 14.1 \\
\hline \multirow[t]{6}{*}{ North America } & $\mathrm{Q}$ (million I\$) & & & & & & & & 213111 & 213111 \\
\hline & $\%$ world & & & & & & & & 13.2 & 13.2 \\
\hline & Labor (million man) & & & & & & & & 3.9 & 3.9 \\
\hline & $\%$ & & & & & & & & 0.3 & 0.3 \\
\hline & Capital (million \$) & & & & & & & & 710364 & 710364 \\
\hline & $\%$ & & & & & & & & 14.1 & 14.1 \\
\hline \multirow[t]{6}{*}{ South. America } & Q (million I\$) & 18 & 397 & & 1970 & 5221 & 18670 & 10087 & 104314 & 140675 \\
\hline & $\%$ world & 0.0 & 0.0 & & 0.1 & 0.3 & 1.2 & 0.6 & 6.4 & 8.7 \\
\hline & Labor (million man) & 0 & 0.1 & & 1.3 & 0.8 & 5.8 & 3.5 & 15.6 & 27.2 \\
\hline & $\%$ & 0 & 0 & & 0.1 & 0.1 & 0.5 & 0.3 & 1.3 & 2.3 \\
\hline & Capital (million \$) & 37 & 1747 & & 7169 & 30188 & 87005 & 96235 & 257504 & 479886 \\
\hline & $\%$ & 0 & 0 & & 0.1 & 0.6 & 1.7 & 1.9 & 5.1 & 9.5 \\
\hline \multirow[t]{6}{*}{ American Caribbean } & $\mathrm{Q}$ (million I\$) & 261 & 634 & 1446 & 1858 & 3694 & & & & 7893 \\
\hline & $\%$ world & 0 & 0 & 0.1 & 0.1 & 0.2 & & & & 0.5 \\
\hline & Labor (million man) & 0.1 & 0.6 & 2.1 & 0.6 & 0.8 & & & & 4.2 \\
\hline & $\%$ & 0 & 0.1 & 0.2 & 0 & 0.1 & & & & 0.4 \\
\hline & Capital (million \$) & 469 & 1426 & 6456 & 8855 & 27014 & & & & 44220 \\
\hline & $\%$ & 0 & 0 & 0.1 & 0.2 & 0.5 & & & & 0.9 \\
\hline \multirow[t]{8}{*}{ Central America } & Q (million I\$) & & 116 & 2569 & 3125 & 2374 & & & 25934 & 34118 \\
\hline & $\%$ world & & 0 & 0.2 & 0.2 & 0.1 & & & 1.6 & 2.1 \\
\hline & Labor (million man) & & 1.2 & 1.3 & 1 & 1.5 & & & 8.4 & 13.4 \\
\hline & $\%$ & & 0.1 & 0.1 & 0.1 & 0.1 & & & 0.7 & 1.2 \\
\hline & Capital (million \$) & & 154 & 10819 & 6298 & 6597 & & & 114772 & 138640 \\
\hline & $\%$ & & 0 & 0.2 & 0.1 & 0.1 & & & 2.3 & 2.8 \\
\hline & Q (million I\$) & 287 & 222 & & 1877 & & & 8004 & 20818 & 31208 \\
\hline & $\%$ world & 0 & 0 & & 0.1 & & & 0.5 & 1.3 & 1.9 \\
\hline \multirow[t]{4}{*}{ Oceania } & Labor (million man) & 0.3 & 0.1 & & 1.5 & & & 0.2 & 0.4 & 2.5 \\
\hline & $\%$ & 0 & 0 & & 0.1 & & & 0 & 0 & 0.2 \\
\hline & Capital (million \$) & 2165 & 932 & & 2130 & & & 57631 & 114139 & 176997 \\
\hline & $\%$ & 0 & 0 & & 0 & & & 1.1 & 2.3 & 3.5 \\
\hline \multirow[t]{6}{*}{ Total } & $\mathrm{Q}$ (million I\$) & 1082 & 5893 & 12833 & 28970 & 60654 & 78601 & 139030 & 1143315 & 1470378 \\
\hline & $\%$ world & 0.1 & 0.4 & 0.8 & 1.8 & 3.7 & 4.9 & 8.6 & 70.6 & 90.9 \\
\hline & Labor (million man) & 1.4 & 7 & 17.4 & 44.2 & 49.3 & 48 & 100.9 & 845.5 & 1113.7 \\
\hline & $\%$ & 0.1 & 0.6 & 1.5 & 3.8 & 4.3 & 4.1 & 8.7 & 72.9 & 96 \\
\hline & Capital (million \$) & 5585 & 23507 & 67745 & 110713 & 274460 & 285389 & 478580 & 3183339 & 4429319 \\
\hline & $\%$ & 0.1 & 0.5 & 1.3 & 2.2 & 5.5 & 5.7 & 9.5 & 63.3 & 88 \\
\hline
\end{tabular}


Table 5. Create the output distance function between two data points and two technology.

\begin{tabular}{|c|c|c|}
\hline \multirow[b]{2}{*}{ Technology } & \multicolumn{2}{|c|}{ Output Distance Function $D_{o}$} \\
\hline & Data point $(t)$ & Data point $(t+1)$ \\
\hline$\left(y^{t}, x^{t}\right)$ & $D_{o}^{t}\left(y^{t}, x^{t}\right) \ldots \ldots \ldots \ldots \ldots \ldots(D f 1)$ & $D_{o}^{t+1}\left(y^{t}, x^{t}\right) \ldots \ldots \ldots \ldots \ldots \ldots(D f 2)$ \\
\hline$\left(y^{t+1}, x^{t+1}\right)$ & $D_{o}^{t}\left(y^{t+1}, x^{t+1}\right) \ldots \ldots \ldots \ldots(D f 3)$ & $D_{o}^{t+1}\left(y^{t+1}, x^{t+1}\right) \ldots \ldots \ldots \ldots(D f 4)$ \\
\hline
\end{tabular}

Table 6. Means of technical efficiency, technical efficiency change, technical change, pure technical efficiency change scale efficiency change, and TFP change for groups, 1980-2007 (based on estimation for countries in each group)

\begin{tabular}{|c|c|c|c|c|c|c|c|c|}
\hline Groups & $\begin{array}{l}\text { Agricultural } \\
\text { gross produc- } \\
\text { tion value } \\
\text { (millions I\$) }\end{array}$ & countries & $\begin{array}{l}\text { technical } \\
\text { efficiency }\end{array}$ & $\begin{array}{l}\text { pure tech- } \\
\text { nical } \\
\text { efficiency } \\
\text { change }\end{array}$ & $\begin{array}{l}\text { scale effi- } \\
\text { ciency } \\
\text { change }\end{array}$ & $\begin{array}{c}\text { Technical } \\
\text { efficiency } \\
\text { change }\end{array}$ & $\begin{array}{l}\text { technical } \\
\text { change }\end{array}$ & $\begin{array}{c}\text { total factor } \\
\text { productivity } \\
\text { change }\end{array}$ \\
\hline Group 1 & Less than 100 & 33 & 0.766 & 1.003 & 0.986 & 0.989 & 1.123 & 1.110 \\
\hline Group 2 & $100-500$ & 25 & 0.676 & 1.000 & 0.980 & 0.980 & 1.099 & 1.077 \\
\hline Group 3 & $500-1000$ & 16 & 0.873 & 1.000 & 0.994 & 0.994 & 1.112 & 1.105 \\
\hline Group 4 & $1000-2000$ & 20 & 0.851 & 1.000 & 0.996 & 0.996 & 1.090 & 1.086 \\
\hline Group 5 & $2000-4000$ & 21 & 0.864 & 1.000 & 0.994 & 0.994 & 1.120 & 1.114 \\
\hline Group 6 & $4000-8000$ & 16 & 0.950 & 1.000 & 0.996 & 0.996 & 1.106 & 1.101 \\
\hline Group 7 & $8000-16000$ & 13 & 0.888 & 1.000 & 0.993 & 0.993 & 1.059 & 1.052 \\
\hline Group 8 & $\begin{array}{l}\text { More than } \\
16000\end{array}$ & 21 & 0.831 & 1.000 & 0.998 & 0.998 & 1.065 & 1.064 \\
\hline Mean & & & 0.817 & 1.001 & 0.991 & 0.992 & 1.100 & 1.091 \\
\hline
\end{tabular}

The overall mean of the technical efficiency for all groups is 0.817 , which explains that those groups are producing $81.7 \%$ of the potential output that could be produced using the observed input. On the other hand, Table (6) shows the mean of the technical efficiency of each group. For instance, group (2) posted the lowest mean of the technical efficiency (0.676), which illustrates that those countries in group (2) are producing 67.6\% of the output that could be potentially produced using the observed input. Group (6) achieved the highest technical efficiency (0.950). This implies that the countries in group (6) are producing 95\% of the output that could be potentially produced using the observed input.

\section{2- Technical efficiency change}

The technical efficiency change is affected by two powers, pure technical efficiency change and scale efficiency change. Table (6) shows the overall mean of the technical efficiency change for all groups is 0.992 which implies that these decline in technical efficiency during $1980-2007$ by $0.8 \%$ annually. The pure technical efficiency change decline due to the decline in scale efficiency change on average $(0.9 \%$ annually), but pure technical efficiency change $(0.1 \%$ annually) plays the posi- tive role to improve this ratio. Table (6) also shows that all groups have no change in pure technical efficiency change except group (1), and all groups have a decline in scale efficiency during 19802007.

\section{3- Malmquist total factor productivity change index.}

Table (6) shows the technical efficiency change, technical change, and TFP change in each group. The Malmquist total factor productivity index is affected by two powers, the technical efficiency change and the technical change. Table (6) shows that the countries in Group (5) posted the highest TFP growth (11.5\%) which is mainly due to the technical change growth of $12 \%$ followed by Group (1) which posted TFP growth of $11 \%$ due to the technical change growth of $12.3 \%$, followed by Group (3) which posted TFP growth of $10.5 \%$ due to the technical change growth of $11.2 \%$, followed by Group (6), Group (4) and Group (8). Meanwhile, Group (7) posted the lowest TFP growth of 5.2\% due to the technical change growth of $5.9 \%$. Table (6) also shows that the main effect drives the total factor productivity growth due to the technical change. 


\section{b. Results for regions}

\section{1- Technical efficiency}

Table (7) shows the means of the technical efficiency for each region during 1980-2007. For instance, the lowest technical efficiency posted for American Caribbean and North America of 0.750 , 0.779 illustrates that two regions are producing $75 \%$ and $77.9 \%$ of the output that could be potentially produced using the observed input in each region respectively. On the other hand, South America and Central America posted the highest technical efficiency of 0.870 and 0.917 which implies this regions producing $87 \%$ and $91.7 \%$ of the output that could be potentially produced using the observed input during studying period respectively. The other regions are very close to one others such as Oceania, Africa, Asia, and Europe are recoded $0.802,0.811,0.815,0.837$ respectively.

Table 7. Means of technical efficiency, technical efficiency change, technical change, pure technical efficiency change scale efficiency change, and TFP change for regions,1980-2007 (based on estimation for countries in each group)

\begin{tabular}{|c|c|c|c|c|c|c|}
\hline 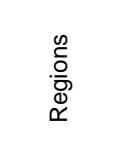 & 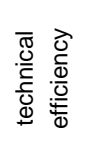 & 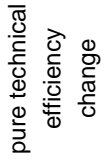 & 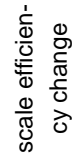 & 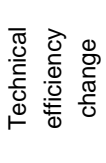 & 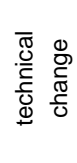 & 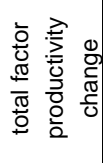 \\
\hline Asia & 0.815 & 1.000 & 0.991 & 0.991 & 1.086 & 1.076 \\
\hline Africa & 0.811 & 1.000 & 0.992 & 0.992 & 1.101 & 1.093 \\
\hline Europe & 0.837 & 1.000 & 0.998 & 0.998 & 1.086 & 1.084 \\
\hline $\begin{array}{c}\text { North } \\
\text { America }\end{array}$ & 0.779 & 1.000 & 1.000 & 1.000 & 1.097 & 1.097 \\
\hline $\begin{array}{l}\text { Central } \\
\text { America }\end{array}$ & 0.917 & 1.000 & 0.994 & 0.994 & 1.108 & 1.101 \\
\hline $\begin{array}{c}\text { American } \\
\text { Carrabin }\end{array}$ & 0.750 & 1.002 & 0.978 & 0.980 & 1.117 & 1.094 \\
\hline $\begin{array}{c}\text { South } \\
\text { America }\end{array}$ & 0.872 & 1.000 & 0.993 & 0.993 & 1.109 & 1.102 \\
\hline Oceania & 0.802 & 1.002 & 0.991 & 0.993 & 1.117 & 1.109 \\
\hline Mean & 0.817 & 1.001 & 0.991 & 0.992 & 1.100 & 1.091 \\
\hline
\end{tabular}

\section{2- Technical efficiency change}

Table (7) shows the means of technical efficiency change for regions. The overall mean technical efficiency change for Asia posted of 0.991 implies this decline in technical efficiency by $0.9 \%$ annually. This decline is mainly due to the decline in scale efficiency change on average $(0.9 \%)$ annually during 1980-2007. While, the pure technical efficiency showed no change for countries in Asia under study, Table (7) also shows that all regions have no change in pure technical efficiency change except American Carrabin and Oceania. In the same time all regions have a decline in scale efficiency except North America during 1980-2007.

\section{3- Malmquist total factor productivity change index.}

Table (7) shows that the Oceania region posted the highest TFP growth of $10.9 \%$ due to technical change growth of $11.7 \%$ followed by South America posted TFP growth of $10.2 \%$ due to to technical change growth of $10.9 \%$, followed by Central America posted TFP growth of $10.1 \%$ due to to technical change growth of $10.8 \%$, followed by North America, American Carrabin, Africa, Europe and Asia. Asia has posted lowest TFP growth of $7.6 \%$ due to technical change growth of $8.6 \%$.

\section{c. The annual change average Malmquist total factor productivity change index}

While Table (9) presents a good panorama about TFP change from year to year during 1980 2007, Table (8) summarizes the results of the Annual Mean of technical efficiency change, technical change, pure technical efficiency change scale efficiency change, and TFP change for groups 1980-2007. Table (8) shows the average TFP change during 1980-1990 declined from $16.9 \%$ to $7.2 \%$ during the period (1991-2000), and posted of $0.4 \%$ as the lowest value for TFP change during the period 2001-2007.

Table 8. Annual Means of technical change and TFP change for groups in some different periods (based on estimation for countries in each group

\begin{tabular}{|c|c|c|c|c|c|c|c|c|c|c|c|c|c|c|c|}
\hline & \multicolumn{3}{|c|}{$1980-1990$} & \multicolumn{3}{|c|}{$1991-2000$} & \multicolumn{3}{|c|}{$1980-2000$} & \multicolumn{3}{|c|}{ 2001-2007 } & \multicolumn{3}{|c|}{$1980-2007$} \\
\hline & Teff.ch. & Tch. & TFPch. & Teff.ch. & Tch. & TFPch. & Teff.ch. & Tch. & TFPch. & Teff.ch. & Tch. & TFPch. & Teff.ch. & Tch. & TFPch. \\
\hline Group 1 & 0.983 & 1.010 & 0.993 & 1.010 & 1.127 & 1.138 & 0.996 & 1.067 & 1.063 & 0.968 & 1.297 & 1.255 & 0.989 & 1.122 & 1.110 \\
\hline Group 2 & 0.952 & 1.315 & 1.253 & 1.051 & 0.992 & 1.043 & 1.001 & 1.142 & 1.143 & 0.922 & 0.984 & 0.907 & 0.980 & 1.099 & 1.077 \\
\hline Group 3 & 0.967 & 1.322 & 1.277 & 1.040 & 0.953 & 0.992 & 1.003 & 1.122 & 1.126 & 0.969 & 1.081 & 1.048 & 0.994 & 1.111 & 1.105 \\
\hline Group 4 & 1.006 & 1.131 & 1.138 & 0.966 & 1.092 & 1.055 & 0.986 & 1.111 & 1.095 & 1.027 & 1.033 & 1.061 & 0.996 & 1.090 & 1.086 \\
\hline Group 5 & 0.938 & 1.306 & 1.226 & 0.983 & 1.133 & 1.114 & 0.960 & 1.216 & 1.168 & 1.097 & 0.886 & 0.972 & 0.994 & 1.121 & 1.114 \\
\hline Group 6 & 0.993 & 1.215 & 1.207 & 0.973 & 1.044 & 1.015 & 0.983 & 1.126 & 1.107 & 1.033 & 1.051 & 1.086 & 0.996 & 1.106 & 1.101 \\
\hline Group 7 & 0.947 & 1.227 & 1.162 & 1.055 & 0.985 & 1.039 & 1.000 & 1.099 & 1.098 & 0.976 & 0.954 & 0.931 & 0.993 & 1.059 & 1.052 \\
\hline Group 8 & 0.869 & 1.291 & 1.122 & 1.157 & 1.035 & 1.198 & 1.003 & 1.156 & 1.159 & 0.984 & 0.845 & 0.832 & 0.998 & 1.065 & 1.064 \\
\hline Mean & 0.956 & 1.222 & 1.169 & 1.028 & 1.043 & 1.072 & 0.991 & 1.129 & 1.120 & 0.996 & 1.008 & 1.004 & 0.993 & 1.097 & 1.088 \\
\hline
\end{tabular}


Table 9. Annual Means of technical efficiency change, technical change, pure technical efficiency change scale efficiency change,and TFP change for groups 1980-2007 (based on estimation for countries in each group)

\begin{tabular}{|c|c|c|c|c|c|c|c|c|c|c|c|c|c|c|c|c|c|}
\hline From & To & $\mathrm{G}$ & Teff.ch. & Tch. & TFPch. & $\bar{G}$ & Teff.ch. & Tch. & TFPch. & $\mathrm{g}$ & Teff.ch. & Tch. & TFPch. & $G$ & h. & Tch. & Pch. \\
\hline 1980 & 1981 & 1 & 1.133 & 0.538 & 0.610 & 3 & 0.588 & 1.555 & 0.914 & 5 & 0.672 & 2.019 & 1.357 & 7 & 0.913 & 0.537 & 0.490 \\
\hline 1981 & 1982 & 1 & 0.190 & 15.058 & 2.864 & 3 & 635 & 0.871 & .423 & & 715 & 681 & 202 & 7 & 398 & .082 & 664 \\
\hline 1982 & 1983 & 1 & 4.396 & 0.343 & 1.508 & 3 & 31 & 887 & & & & .792 & 42 & 7 & & .561 & .707 \\
\hline 1983 & 1984 & 1 & 0.654 & 0.476 & 0.311 & 3 & 1.549 & 0.688 & 1.065 & 5 & 1.196 & 1.268 & 1.517 & r & 735 & 2.779 & 2.043 \\
\hline 1984 & 1985 & 1 & 0.928 & 0.752 & 0.697 & 3 & 1.082 & 1.307 & 1.414 & 5 & 0.938 & 1.289 & 1.209 & 7 & 28 & 0.595 & .612 \\
\hline 1985 & 1986 & 1 & 1.233 & 1.149 & 1.418 & 3 & 1.049 & 0.630 & 0.661 & & & 1.089 & 1.152 & 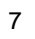 & 96 & 2.112 & .682 \\
\hline 1986 & 1987 & 1 & 1.384 & 0.984 & 1.362 & 3 & 06 & 1.954 & 965 & 5 & 26 & 0.766 & 0.863 & 7 & 84 & 794 & 257 \\
\hline 1987 & 1988 & 1 & 0.324 & 5.039 & 1.631 & 3 & 0.489 & 2.511 & 1.227 & 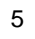 & & 2.272 & 2.275 & 7 & & 199 & 00 \\
\hline 1988 & 1989 & 1 & 3.267 & 0.370 & 1.210 & 3 & 1.799 & 0.872 & 1.569 & 5 & 26 & 1.551 & 1.127 & 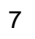 & & 0.720 & .935 \\
\hline 1989 & 1990 & 1 & 0.814 & 0.527 & 0.429 & 3 & 0.755 & 1.715 & 1.295 & 5 & 68 & 1.119 & 0.747 & 7 & 67 & 1.428 & 952 \\
\hline 1990 & 1991 & 1 & 1.188 & 2.300 & 2.732 & 3 & 1.076 & 0.569 & 0.613 & 5 & 19 & 0.807 & 45 & 7 & & 0.840 & 494 \\
\hline 1991 & 1992 & 1 & 0.215 & 2.708 & 0.582 & 3 & 1.056 & 1.434 & 1.514 & 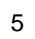 & 1.248 & & 1.415 & r & & 0.784 & 630 \\
\hline 1992 & 1993 & 1 & 4.467 & 0.377 & 1.684 & 3 & 0.989 & 0.521 & 0.515 & 5 & 29 & 1.375 & 1.278 & 7 & 227 & 0.908 & 1.115 \\
\hline 1993 & 1994 & 1 & 0.476 & 1.665 & 0.793 & 3 & 1.183 & 1.829 & 2.165 & 5 & 1.152 & 0.848 & 0.977 & 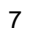 & & 0.614 & 0.658 \\
\hline 1994 & 1995 & 1 & 1.978 & 1.3 & 2.601 & 3 & 84 & 8 & 76 & & 27 & 0.776 & 97 & 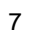 & & 825 & 499 \\
\hline 1995 & 1996 & 1 & 0.486 & 0.660 & 0.320 & 3 & 1.229 & 0.934 & 1.147 & 5 & 0.739 & 1.614 & 1.193 & 7 & 09 & 0.580 & 0.585 \\
\hline 1996 & 1997 & 1 & 1.738 & 1.480 & 2.572 & 3 & 0.969 & 1.453 & 1.409 & 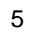 & 0.845 & 1.263 & 1.067 & 7 & & 1.406 & 1.526 \\
\hline 1997 & 1998 & 1 & 0.742 & 1.188 & 0.882 & 3 & 32 & 2 & 16 & & & 0.6 & 80 & 7 & & 0.606 & 573 \\
\hline 1998 & 1999 & 1 & 1.576 & 0.677 & 1.067 & 3 & 1.027 & 1.270 & 1.305 & 5 & 0.973 & 0.738 & 0.717 & 7 & & 2.925 & 1.793 \\
\hline 1999 & 2000 & 1 & 1.039 & 0.8 & 0.852 & 3 & & 0 & & & & & & 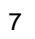 & & & 23 \\
\hline 2000 & 2001 & 1 & 1.200 & 0.6 & 0.768 & 3 & 0.791 & 1.926 & 1.524 & 5 & 2. & 0.4 & 0.873 & 7 & 32 & 27 & 1.219 \\
\hline 2001 & 2002 & 1 & 0.412 & 4.98 & 2.053 & 3 & 0.547 & 1.962 & 1.073 & 5 & & 0.809 & 0.930 & 7 & & 0.902 & 0.889 \\
\hline 2002 & 2003 & 1 & 2 & 0. & & 3 & & & & & & & & r & & & 17 \\
\hline 2003 & 2004 & 1 & 0.645 & 0.467 & 0.301 & 3 & 1.180 & 0.836 & 0.986 & 5 & 1.033 & 1.330 & 1.373 & 7 & 33 & 0.820 & 0.971 \\
\hline 2004 & 2005 & 1 & 0.687 & 7.385 & 5.072 & 3 & 0.945 & 0.642 & 0.607 & 5 & & $1 . \varsigma$ & 15 & 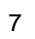 & & 89 & 0.979 \\
\hline 2005 & 2006 & 1 & 2.026 & 0.286 & 0.5 & 3 & 0.8 & 1 & 1. & 5 & & 0.8 & 2 & r & & 3 & 1.017 \\
\hline 2006 & 2007 & 1 & 0.825 & 2.220 & 1.832 & 3 & 1.119 & 0.567 & 0.635 & 5 & 1.057 & 0.828 & 0.875 & 7 & 26 & 0.474 & 0.439 \\
\hline \multicolumn{2}{|c|}{ Mean } & 1 & 0.989 & 1.122 & 1.110 & 3 & 0.994 & 1.111 & 1.105 & 5 & 0.994 & 1.121 & 1.114 & 7 & 93 & 1.059 & 1.052 \\
\hline 1980 & 1981 & 2 & 1.016 & 1.734 & 1.763 & 4 & 0.464 & 2.766 & 1.284 & 6 & 0. & & & 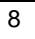 & & 2.778 & 1.782 \\
\hline 1981 & 1982 & 2 & 1.109 & 0.775 & 0.860 & 4 & 1.436 & 0.747 & 1.073 & 6 & 1.368 & 1.207 & 51 & 8 & & 0.700 & 1.089 \\
\hline 1982 & 1983 & 2 & 1.002 & 1.2 & 1.2 & 4 & & & & 6 & & & & 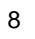 & & & 177 \\
\hline 1983 & 1984 & 2 & 1.139 & 0.690 & 0.786 & 4 & 0.693 & 3.018 & 2.091 & 6 & 0. & 0.6 & 99 & 8 & & 4.936 & 5.501 \\
\hline 1984 & 1985 & 2 & 0.531 & 2.275 & 1.209 & 4 & 0.953 & 1.074 & 1.023 & 6 & 02 & 2. & 66 & 8 & & 0.419 & 0.372 \\
\hline 1985 & 1986 & 2 & & & & 4 & & & & & & & & 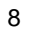 & & & 0.713 \\
\hline 1986 & 1987 & 2 & 0.633 & 1.853 & 1.172 & 4 & 1.007 & 2.590 & 2.609 & 6 & 1.123 & 1.582 & 1.777 & 8 & & 0.540 & 2.742 \\
\hline 1987 & 1988 & 2 & 1.657 & 0 & 1.278 & 4 & 3 & 0 & 2 & $\epsilon$ & & 6 & 39 & 8 & & 73 & 11 \\
\hline 1988 & 1989 & 2 & 0.985 & 0. & 0.769 & 4 & & 0.7 & & & & & & 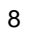 & & 0. & 0.558 \\
\hline 1989 & 1990 & 2 & 0.575 & 4.561 & 2.623 & 4 & 1.309 & 0.9 & 1.190 & 6 & 1.331 & 0.638 & 0.848 & 8 & 60 & 3.650 & 0.950 \\
\hline 90 & 1991 & 2 & 43 & 0. & 0 & 4 & & & & 6 & & & & 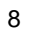 & & 0.484 & 1.661 \\
\hline 1991 & 1992 & 2 & 1.151 & 0.60 & 0.692 & 4 & 1.002 & 0.9 & 0.934 & 6 & 0.783 & 2.363 & 1.849 & 8 & & 4.023 & 3.222 \\
\hline 1992 & 1993 & 2 & 0.410 & 3.024 & 1.239 & 4 & 1.138 & 0.7 & 53 & 6 & 1.304 & 0.5 & 53 & 8 & 95 & 36 & .537 \\
\hline 1993 & 1994 & 2 & 2.218 & 0.4 & 1.096 & 4 & & & & 6 & & & & 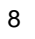 & & 1.463 & 1.081 \\
\hline 1994 & 1995 & 2 & 0.683 & 0.982 & 0.671 & 4 & 1.238 & 0.798 & 0.988 & 6 & 0.803 & 1.009 & 0.810 & 8 & 76 & 0.863 & 1.274 \\
\hline 1995 & 1996 & 2 & 1.618 & 0.807 & 1.305 & 4 & 0.821 & 26 & 0.760 & 6 & 37 & 0.7 & 0.908 & 8 & 28 & 1.313 & 1.088 \\
\hline 1996 & 1997 & 2 & 0.328 & 2.323 & 0.762 & 4 & 1. & 0.849 & 0.8 & 6 & & 1. & 1.221 & 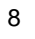 & & 2.029 & 1.328 \\
\hline 1997 & 1998 & 2 & 2.369 & 0.700 & 1.658 & 4 & 1.1 & 1.286 & 1.453 & 6 & 32 & 0. & 0.862 & 8 & 25 & 0.811 & 0.831 \\
\hline 1998 & 1999 & 2 & 1.348 & & 0.717 & 4 & & & & 6 & & & & 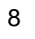 & & 0.635 & 0.827 \\
\hline 1999 & 2000 & 2 & 0.738 & 3.226 & 2.381 & 4 & 1.099 & 0.682 & 0.749 & 6 & 0.866 & 0.576 & 0.499 & 8 & 1.246 & 1.239 & 1.543 \\
\hline 2000 & 2001 & 2 & 1.186 & 0.484 & 0.573 & 4 & 1.5 & 1.008 & 1.5 & 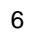 & 1.2 & 2. & 2.691 & 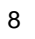 & 16 & 0.992 & 1.008 \\
\hline 2001 & 2002 & 2 & 0.656 & 2.238 & 1.467 & 4 & 0.930 & 1.108 & 1.031 & 6 & 0.576 & 1.287 & 0.741 & 8 & 0.632 & 1.527 & 0.964 \\
\hline 2002 & 2003 & 2 & 1.603 & 0.814 & 1.305 & 4 & & 1.557 & 0.838 & 6 & & 0.779 & 1.249 & 8 & 1.271 & 0.771 & 0.980 \\
\hline 2003 & 2004 & 2 & 0.571 & 1.666 & 0.951 & 4 & 1.532 & 1.010 & & 6 & & 1.243 & 1.039 & 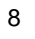 & & 1.038 & 1.156 \\
\hline 2004 & 2005 & 2 & 1.843 & 0.862 & 1.590 & 4 & 1.109 & 0.885 & 0.981 & 6 & 1.273 & 0.664 & 0.845 & ర & 0.949 & 1.254 & 1.191 \\
\hline 2005 & 2006 & 2 & 0.779 & 1.136 & 0.885 & 4 & 0.937 & 1.044 & 0.979 & 0 & 0.888 & 1.461 & 1.297 & o & 1.202 & 0.641 & 0.771 \\
\hline 006 & 2007 & 2 & 0.556 & 0.621 & 0.345 & 4 & 0.998 & 0.774 & 0.772 & 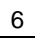 & 1.120 & 0.561 & 0.628 & 8 & 0.865 & 0.315 & 0.272 \\
\hline \multicolumn{2}{|c|}{ Mean } & 2 & 0.980 & 1.099 & 1.077 & 4 & 0.996 & 1.090 & 1.086 & 6 & 0.996 & 1.106 & 1.101 & 8 & 0.998 & 1.065 & 1.064 \\
\hline
\end{tabular}

Teff.: technical efficiency, Teff.ch.: technical efficiency change,Tch.:, technical change, TFPch.: total factor productivity change,

Source :results of Data Envelopment Analysis (DEA) 
Table (8) shows that the countries on group (2) posted the highest TFP change during period 1980-1990, while the countries on group (8) posted $19.8 \%$ as a highest TFP change during the period 1991-2000. On the other hand, the countries on group (5) posted highest TFP change during period (1980-2000), but the countries on group (1) posted the highest TFP change during period (2001-2007).

\section{2- The results depends on estimation for all countries as one group}

\section{a- Results for groups : \\ 1- Technical efficiency change}

Table (10) shows that the overall means of the technical efficiency change for all groups is 1.014 which implies that this growth in technical efficiency during study period by $1.4 \%$ annually on average. This is mainly due to the pure technical efficiency change (about $2.4 \%$ annually) which played a positive role to improve this ratio. On the other hand, Table (10) shows that the scale efficiency change on average is decline (about - $0.9 \%$ annually) in the same period. Table (10) shows that the Technical efficiency growth is positive for all groups except group (7), Group (8) posted the highest technical efficiency growth of $2.8 \%$ followed by Group (1) and group (5) which posted the technical efficiency growth of $2.1 \%, 2 \%$ respectively, while group (3) and group (6) posted technical efficiency growth of $1.9,1.8 \%$ respectively.

Table 10. Means of technical efficiency, technical efficiency change, technical change, pure technical efficiency change scale efficiency change,and TFP change for groups, 19802007 (based on estimation for countries as one group)

\begin{tabular}{|c|c|c|c|c|c|c|}
\hline 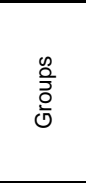 & 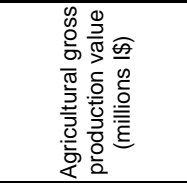 & 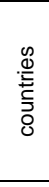 & 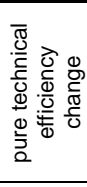 & 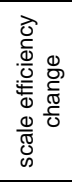 & 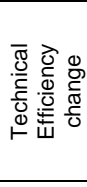 & 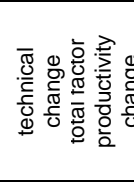 \\
\hline Group 1 & sst & 33 & 26 & 0. & 1.021 & 1139 \\
\hline Group 2 & 100 & 25 & 1.020 & 0.988 & 1.008 & 1.1201 .12 \\
\hline 3 & $500-$ & 16 & 1.022 & 0.997 & 1.019 & 1.0991 .12 \\
\hline Group 4 & 0 & 20 & 29 & 0.983 & 1.011 & 1.10 \\
\hline & $0 \Omega$ & 21 & 4 & 0.996 & 18 & 1 \\
\hline Group 6 & $4000-8000$ & 16 & 4 & 0. & 1.018 & 1.100 \\
\hline Group 7 & $8000-16000$ & 13 & .016 & 0.959 & 0.974 & 1.1491 .11 \\
\hline Group 8 & 6000 & 21 & 26 & 1.002 & 1.028 & 1.1131 .14 \\
\hline Mean & & 165 & 1.024 & 0.991 & 1.014 & 1.1271 .14 \\
\hline
\end{tabular}

Source: calculation from table (14)

\section{2- Malmquist Total Factor Productivity change index.}

Table (10) shows that the measures of TFP change by different groups. The main effect which drive the total factor productivity growth due to the technical change, Table (10) shows that the countries on Group (6) posted the highest TFP growth of $17.1 \%$ due mainly to technical change growth of $15 \%$ and $1.8 \%$ due to technical efficiency change, followed by group (5) which posted TFP growth of $16.7 \%$ due to the technical change growth of 14.4 $\%$, followed by group (1) which posted TFP growth of $16.3 \%$ due to the technical change growth of $13.9 \%$, followed by group (8), group (2), group (3).While, group (4) posted the lowest TFP growth of $11.6 \%$ due to the technical change growth of $10.4 \%$.

\section{b- Results for Regions:}

\section{1- Technical Efficiency Change}

Table (11) shows that the overall means of the technical efficiency change for all regions is 1.014 which implies that this technical efficiency growth during study period by $1.4 \%$ annually on average. This mainly due to the pure technical efficiency change (about $2.4 \%$ annually) which play a positive role to improve this ratio. On the other hand, Table (11) shows the scale efficiency change on average is decline.

Table 11. Means of technical efficiency, technical efficiency change, technical change, pure technical efficiency change scale efficiency change, and TFP change for regions, 1980-2007 (based on estimation for countries as one group)

\begin{tabular}{|c|c|c|c|c|c|}
\hline 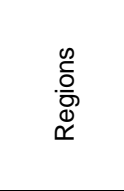 & 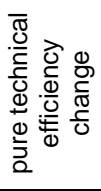 & 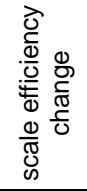 & 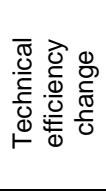 & 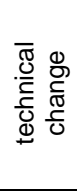 & 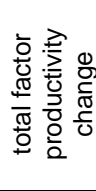 \\
\hline Asia & 1.021 & 1.001 & 1.022 & 1.116 & 1.141 \\
\hline Africa & 1.024 & 0.985 & 1.008 & 1.127 & 1.136 \\
\hline Europe & 1.024 & 0.997 & 1.021 & 1.116 & 1.139 \\
\hline North & 1.033 & 0.963 & 0.995 & 1.133 & 1.127 \\
\hline Central & 1.026 & 0.985 & 1.011 & 1.110 & 1.122 \\
\hline American & 1.027 & 0.996 & 1.022 & 1.127 & 1.152 \\
\hline South & 1.031 & 0.987 & 1.018 & 1.166 & 1.187 \\
\hline Oceania & 1.022 & 0.978 & 1.000 & 1.147 & 1.147 \\
\hline Mean & 1.024 & 0.991 & 1.014 & 1.127 & 1.143 \\
\hline
\end{tabular}

Source: calculation from table (14) 
2- Malmquist total factor productivity change index.

Table (11) shows that the overall mean of TFP change for all regions is $14.3 \%$ due to the technical change growth $12.7 \%$. Table (11) shows that South America posted the highest TFP growth of $18.7 \%$ mainly due to technical change growth of $16.6 \%$ and $1.8 \%$ due to technical efficiency change, followed by a American Carrabin posted TFP growth of $15.2 \%$ due to the technical change growth of $12.7 \%$, followed by Oceania which posted TFP growth of $14.7 \%$ due to the technical change growth of $14.7 \%$, followed by Asia, Europe, Africa. On the other hand, Central America posted the lowest TFP growth of $12.2 \%$ due to the technical change growth of $11 \%$. Table (11) shows the main effect which drive the total factor productivity growth due to the technical change during the 1980-2007.

\section{c- The annual change average Malmquist total factor productivity change index}

Table (12) basically summarize Table (13); Table (12) shows the Annual Means technical efficiency change, technical change and TFP change for 165 countries during 1980-2007. Table (12) shows that the average TFP change during 19801990 was $32.3 \%$ due to the technical change growth of $26.4 \%$. The TFP change declined to $3.7 \%$ during the period $(1991-2000)$ due to the technical change growth of $4.7 \%$, but TFP change is increase and posted of $6.6 \%$ due to the technical change growth of $6.2 \%$ during the period 2001 2007. On the other hand, the TFP change posted $17.1 \%$ during (1980-2000) and posted $14.3 \%$ during the period (1980-2007) due to technical change of $15.1 \%, 12.7 \%$ respectively.

\section{Results for countries}

\section{1- Results for countries based on estimation for countries in each group.}

Table (14) shows that there are 148 countries that had positive TFP growth from 1980 to 2007, while there are 16 countries that had TFP decline from 1980 to 2007 across groups. On the other, hand one country (Brunei Darussalam) had no change in TFP during the same period. Also, there are 154 countries that had positive technical change and 11 countries that had decline technical change from 1980 to 2007. While, there are 25 countries that only had positive technical efficiency change, 122 countries had a decline in technical efficiency. Also, there are 15 countries that showed no change from 1980 to 2007.

Table 12. Annual Means of technical change and TFP change for groups in some different periods (based on estimation for countries as one group)

\begin{tabular}{|lcccccccccccccc}
\hline \multicolumn{3}{|c}{$1980-1990$} & \multicolumn{3}{c}{$1991-2000$} & \multicolumn{2}{c}{$2001-2007$} & & $1980-2000$ & $1980-2007$ \\
\hline Teff.ch. & Tch. & TFPch. & Teff.ch. & Tch. & TFPch. & Teff.ch. & Tch. & TFPch. & Teff.ch. & Tch. & TFPch. & Teff.ch. & Tch. & TFPch. \\
\hline 1.047 & 1.264 & 1.323 & 0.990 & 1.047 & 1.037 & 1.003 & 1.062 & 1.066 & 1.018 & 1.151 & 1.171 & 1.014 & 1.127 & 1.143 \\
\hline
\end{tabular}

Table 13. Annual Means technical efficiency change, technical change, pure technical efficiency change scale efficiency change, and TFP change for 165 countries (based on estimation for countries as one group)

\begin{tabular}{|cccccccccccccccc|}
\hline from & to & Teff.ch. & Tch. & TFPch. & from & to & Teff.ch. & Tch. & TFPch. & from & to & Teff.ch. Tch. TFPch. \\
\hline 1980 & 1981 & 1.414 & 1.249 & 1.766 & 1990 & 1991 & 1.049 & 0.512 & 0.537 & 2000 & 2001 & 2.817 & 1.141 & 3.213 \\
1981 & 1982 & 0.787 & 2.668 & 2.101 & 1991 & 1992 & 1.242 & 0.654 & 0.812 & 2001 & 2002 & 0.398 & 1.341 & 0.534 \\
1982 & 1983 & 1.595 & 0.874 & 1.394 & 1992 & 1993 & 0.777 & 4.004 & 3.113 & 2002 & 2003 & 1.251 & 0.42 & 0.526 \\
1983 & 1984 & 0.788 & 1.123 & 0.884 & 1993 & 1994 & 1.452 & 0.461 & 0.669 & 2003 & 2004 & 0.673 & 1.573 & 1.059 \\
1984 & 1985 & 1.191 & 0.983 & 1.17 & 1994 & 1995 & 0.779 & 3.107 & 2.422 & 2004 & 2005 & 1.638 & 0.81 & 1.327 \\
1985 & 1986 & 0.839 & 1.457 & 1.222 & 1995 & 1996 & 1.256 & 0.254 & 0.319 & 2005 & 2006 & 0.679 & 2.125 & 1.444 \\
1986 & 1987 & 1.389 & 1.093 & 1.519 & 1996 & 1997 & 0.662 & 2.585 & 1.71 & 2006 & 2007 & 0.975 & 0.877 & 0.855 \\
1987 & 1988 & 0.782 & 1.97 & 1.541 & 1997 & 1998 & 1.06 & 0.637 & 0.676 & 1980 & 2007 & 1.014 & 1.127 & 1.143 \\
1988 & 1989 & 1.35 & 0.698 & 0.942 & 1998 & 1999 & 2.116 & 0.286 & 0.605 & & & & & & \\
1989 & 1990 & 0.771 & 1.482 & 1.143 & 1999 & 2000 & 0.424 & 6.908 & 2.93 & & & & &
\end{tabular}


Table 14. Agricultural gross production value $(Q)$, Means technical efficiency, technical efficiency change, technical change, pure technical efficiency change scale efficiency change, and TFP change for 165 countries, 1980-2007

\begin{tabular}{|c|c|c|c|c|c|c|c|c|c|c|c|c|c|c|c|c|}
\hline \multirow{2}{*}{ G } & \multirow{2}{*}{ Contries } & \multirow{2}{*}{ Regions } & \multicolumn{7}{|c|}{ Estimation for countries in each groups } & & \multicolumn{5}{|c|}{ Estimation for countries as one groups } & \multirow{2}{*}{$\mathrm{O} 2$} \\
\hline & & & IS million & Teff. & PTeff.ch & Seff.ch. & Teff.ch. & Tch. & TFPch. & & $\begin{array}{l}\text { PTeff.ch. } \\
\text {. }\end{array}$ & Seff.ch. & Teff.ch. & Tch. & TFPch. & \\
\hline 1 & $\begin{array}{l}\text { Sao Tome and } \\
\text { Princine }\end{array}$ & Africa & 19 & 0.458 & 1.013 & 1.005 & 1.018 & 1.161 & 1.183 & 1 & 1.007 & 0.995 & 1.001 & 1.163 & 1.164 & 73 \\
\hline 1 & Seychelles & Africa & 6 & 0.502 & 1.011 & 1.004 & 1.015 & 1.162 & 1.180 & 2 & 1.007 & 0.995 & 1.002 & 1.174 & 1.176 & 59 \\
\hline 1 & Samoa & Oceania & 48 & 0.430 & 1.014 & 1.007 & 1.021 & 1.152 & 1.176 & 3 & 1.007 & 0.994 & 1.001 & 1.172 & 1.173 & 63 \\
\hline 1 & Western Sahara & Africa & 7 & 0.609 & 1.000 & 1.005 & 1.005 & 1.170 & 1.176 & 4 & 1.000 & 0.925 & 0.925 & 1.218 & 1.127 & 107 \\
\hline 1 & Maldives & Asia & 11 & 0.554 & 1.009 & 1.005 & 1.014 & 1.153 & 1.169 & 5 & 1.000 & 0.922 & 0.922 & 1.093 & 1.007 & 151 \\
\hline 1 & Malta & Europe & 71 & 0.674 & 1.006 & 1.000 & 1.006 & 1.162 & 1.168 & 6 & 1.000 & 0.915 & 0.915 & 1.090 & 0.997 & 157 \\
\hline 1 & Vanuatu & Oceania & 63 & 0.609 & 1.000 & 1.006 & 1.006 & 1.155 & 1.162 & 7 & 1.000 & 0.924 & 0.924 & 1.250 & 1.155 & 79 \\
\hline 1 & Solomon Islands & Oceania & 78 & 1.000 & 1.000 & 0.988 & 0.988 & 1.171 & 1.157 & 8 & 1.007 & 0.996 & 1.002 & 1.175 & 1.178 & 55 \\
\hline 1 & Guadeloupe & A. Carrabin & 87 & 0.936 & 1.001 & 0.996 & 0.996 & 1.159 & 1.155 & 9 & 1.026 & 1.038 & 1.065 & 1.090 & 1.161 & 75 \\
\hline 1 & Grenada & A. Carrabin & 19 & 0.954 & 1.001 & 0.996 & 0.996 & 1.157 & 1.153 & 10 & 1.026 & 1.023 & 1.050 & 1.099 & 1.153 & 83 \\
\hline 1 & New Caledonia & Oceania & 22 & 0.622 & 1.007 & 1.002 & 1.009 & 1.141 & 1.151 & 11 & 1.003 & 0.901 & 0.904 & 1.128 & 1.019 & 144 \\
\hline 1 & Saint Kitts and Nevis & A. Carrabin & 10 & 0.553 & 1.009 & 1.003 & 1.012 & 1.132 & 1.145 & 12 & 1.007 & 0.993 & 0.999 & 1.108 & 1.108 & 122 \\
\hline 1 & Kiribati & Oceania & 17 & 0.846 & 1.002 & 0.996 & 0.999 & 1.145 & 1.143 & 13 & 1.026 & 1.111 & 1.140 & 1.027 & 1.171 & 66 \\
\hline 1 & $\begin{array}{l}\text { United States Virgin } \\
\text { Islands }\end{array}$ & A. Carrabin & 3 & 0.636 & 1.000 & 1.005 & 1.005 & 1.130 & 1.135 & 14 & 1.000 & 0.931 & 0.931 & 1.228 & 1.143 & 92 \\
\hline 1 & Guam & Oceania & 8 & 0.918 & 1.001 & 0.995 & 0.997 & 1.138 & 1.134 & 15 & 1.026 & 1.048 & 1.076 & 1.087 & 1.169 & 69 \\
\hline 1 & Qatar & Asia & 32 & 0.574 & 1.009 & 1.002 & 1.011 & 1.118 & 1.130 & 16 & 1.007 & 0.989 & 0.995 & 1.081 & 1.076 & 78 \\
\hline 1 & Tonga & Oceania & 27 & 0.764 & 1.000 & 0.998 & 0.998 & 1.133 & 1.130 & 17 & 1.000 & 0.950 & 0.950 & 1.218 & 1.157 & 132 \\
\hline 1 & Iceland & Europe & 93 & 0.846 & 1.002 & 0.997 & 0.999 & 1.126 & 1.125 & 18 & 1.026 & 1.087 & 1.115 & 0.989 & 1.103 & 124 \\
\hline 1 & Saint Lucia & A. Carrabin & 49 & 0.474 & 1.012 & 1.005 & 1.017 & 1.097 & 1.116 & 19 & 1.007 & 0.993 & 1.000 & 1.154 & 1.154 & 80 \\
\hline 1 & Comoros & Africa & 54 & 0.966 & 1.001 & 1.000 & 1.000 & 1.114 & 1.114 & 20 & 1.041 & 0.979 & 1.019 & 1.176 & 1.199 & 42 \\
\hline 1 & Cape Verde & Africa & 30 & 1.000 & 1.000 & 1.000 & 1.000 & 1.113 & 1.113 & 21 & 1.068 & 1.128 & 1.205 & 1.054 & 1.270 & 11 \\
\hline 1 & $\begin{array}{l}\text { Saint Vincent and the } \\
\text { Grenadines }\end{array}$ & A. Carrabin & 28 & 0.489 & 1.012 & 1.004 & 1.016 & 1.092 & 1.110 & 22 & 1.007 & 0.994 & 1.000 & 1.168 & 1.169 & 70 \\
\hline 1 & French Polynesia & Oceania & 22 & 1.000 & 1.000 & 0.996 & 0.996 & 1.112 & 1.108 & 23 & 1.041 & 0.996 & 1.036 & 1.139 & 1.180 & 4 \\
\hline 1 & Gambia & Africa & 96 & 0.996 & 1.000 & 0.995 & 0.995 & 1.113 & 1.108 & 24 & 1.042 & 1.128 & 1.175 & 1.136 & 1.335 & 53 \\
\hline 1 & French Guiana & S. America & 18 & 0.927 & 1.001 & 0.998 & 0.999 & 1.098 & 1.097 & 25 & 1.041 & 0.996 & 1.036 & 1.158 & 1.200 & 40 \\
\hline 1 & Dominica & A. Carrabin & 35 & 0.998 & 1.000 & 0.998 & 0.998 & 1.094 & 1.092 & 26 & 1.041 & 0.993 & 1.033 & 1.204 & 1.244 & 22 \\
\hline 1 & Djibouti & Africa & 43 & 1.000 & 1.000 & 0.999 & 0.999 & 1.080 & 1.079 & 27 & 1.041 & 0.992 & 1.033 & 1.220 & 1.260 & 14 \\
\hline 1 & Equatorial Guinea & Africa & 36 & 0.995 & 1.000 & 0.998 & 0.998 & 1.070 & 1.067 & 28 & 1.041 & 0.995 & 1.035 & 1.208 & 1.251 & 19 \\
\hline 1 & Brunei Darussalam & Asia & 17 & 0.998 & 0.999 & 0.906 & 0.905 & 1.106 & 1.000 & 29 & 1.067 & 0.995 & 1.062 & 1.124 & 1.194 & 47 \\
\hline 1 & British Virgin Islands & A. Carrabin & 1 & 0.984 & 0.999 & 0.907 & 0.906 & 1.093 & 0.990 & 30 & 1.067 & 0.995 & 1.062 & 1.126 & 1.195 & 45 \\
\hline 1 & American Samoa & Oceania & 3 & 1.000 & 0.999 & 0.915 & 0.914 & 1.075 & 0.982 & 31 & 1.067 & 0.980 & 1.046 & 1.094 & 1.144 & 91 \\
\hline 1 & Antigua and Barbuda & A. Carrabin & 9 & 1.000 & 0.999 & 0.911 & 0.910 & 1.072 & 0.975 & 32 & 1.067 & 0.985 & 1.052 & 1.125 & 1.183 & 49 \\
\hline 1 & Bahamas & A. Carrabin & 22 & 0.983 & 0.999 & 0.907 & 0.907 & 1.066 & 0.966 & 33 & 1.067 & 0.991 & 1.057 & 1.179 & 1.247 & 21 \\
\hline 2 & Botswana & Africa & 213 & 0.939 & 1.000 & 1.001 & 1.001 & 1.120 & 1.121 & 1 & 1.067 & 0.994 & 1.061 & 1.153 & 1.223 & 31 \\
\hline 2 & Congo & Africa & 242 & 0.987 & 1.000 & 0.998 & 0.998 & 1.119 & 1.117 & 2 & 1.041 & 0.983 & 1.023 & 1.173 & 1.200 & 41 \\
\hline 2 & Bhutan & Asia & 110 & 1.000 & 1.000 & 1.000 & 1.000 & 1.112 & 1.112 & 3 & 1.067 & 0.993 & 1.060 & 1.162 & 1.231 & 28 \\
\hline 2 & Cyprus & Asia & 409 & 0.981 & 1.000 & 0.999 & 0.999 & 1.108 & 1.106 & 4 & 1.041 & 0.990 & 1.030 & 1.206 & 1.241 & 24 \\
\hline 2 & Fiji & Oceania & 222 & 0.996 & 1.000 & 0.991 & 0.991 & 1.110 & 1.100 & 5 & 1.041 & 0.995 & 1.035 & 1.172 & 1.213 & 35 \\
\hline 2 & Gabon & Africa & 214 & 0.964 & 1.000 & 0.987 & 0.987 & 1.109 & 1.095 & 6 & 1.041 & 0.996 & 1.036 & 1.137 & 1.179 & 54 \\
\hline 2 & Guinea-Bissau & Africa & 172 & 0.859 & 1.000 & 0.990 & 0.990 & 1.099 & 1.088 & 7 & 1.026 & 1.068 & 1.096 & 0.953 & 1.045 & 137 \\
\hline 2 & Belize & C. America & 116 & 1.000 & 1.000 & 1.000 & 1.000 & 1.086 & 1.086 & 8 & 1.067 & 0.992 & 1.059 & 1.150 & 1.218 & 32 \\
\hline 2 & United Arab Emirates & Asia & 451 & 0.385 & 1.000 & 0.982 & 0.982 & 1.106 & 1.086 & 9 & 1.000 & 0.940 & 0.940 & 1.192 & 1.120 & 117 \\
\hline 2 & Sierra Leone & Africa & 435 & 0.492 & 1.000 & 0.970 & 0.970 & 1.110 & 1.076 & 10 & 1.007 & 0.996 & 1.002 & 1.179 & 1.182 & 50 \\
\hline 2 & Namibia & Africa & 387 & 0.594 & 1.000 & 0.967 & 0.967 & 1.107 & 1.071 & 11 & 1.001 & 0.900 & 0.901 & 1.135 & 1.023 & 141 \\
\hline 2 & Suriname & S. America & 116 & 0.448 & 1.000 & 0.975 & 0.975 & 1.097 & 1.070 & 12 & 1.007 & 1.087 & 1.094 & 1.237 & 1.353 & 3 \\
\hline 2 & Mauritius & Africa & 240 & 0.640 & 1.000 & 0.965 & 0.965 & 1.107 & 1.069 & 13 & 1.000 & 0.909 & 0.910 & 1.119 & 1.018 & 146 \\
\hline 2 & Guyana & S. America & 280 & 0.889 & 1.000 & 0.981 & 0.981 & 1.088 & 1.067 & 14 & 1.026 & 1.073 & 1.101 & 0.928 & 1.022 & 143 \\
\hline 2 & Trinidad and Tobago & A. Carrabin & 139 & 0.449 & 1.000 & 0.976 & 0.976 & 1.092 & 1.065 & 15 & 1.000 & 0.948 & 0.948 & 1.188 & 1.126 & 109 \\
\hline 2 & Martinique & A. Carrabin & 109 & 0.652 & 1.000 & 0.974 & 0.974 & 1.091 & 1.063 & 16 & 1.000 & 0.913 & 0.912 & 1.095 & 0.999 & 155 \\
\hline 2 & Lesotho & Africa & 122 & 0.762 & 1.000 & 0.977 & 0.977 & 1.085 & 1.061 & 17 & 1.026 & 1.087 & 1.115 & 1.050 & 1.170 & 67 \\
\hline
\end{tabular}


Table 14. Cont

\begin{tabular}{|c|c|c|c|c|c|c|c|c|c|c|c|c|c|c|c|c|}
\hline \multirow{2}{*}{ G } & \multirow{2}{*}{ Countries } & \multirow{2}{*}{ Regions } & \multirow{2}{*}{$\frac{\mathrm{Q}}{\mathrm{IS} \text { million }}$} & \multicolumn{6}{|c|}{ Estimation for countries in each groups } & \multirow{2}{*}{01} & \multicolumn{5}{|c|}{ Estimation for countries as one groups } & \multirow{2}{*}{$\mathrm{O} 2$} \\
\hline & & & & Teff. & PTeff.c & Seff.ch. & Teff.ch & Tch. & TFPch & & PTeff.ch. & Seff.ch. & Teff.ch & Tch. & TFPch & \\
\hline 2 & Liberia & Africa & 332 & 0.781 & 1.000 & 0.973 & 0.973 & 1.090 & 1.061 & 18 & 1.000 & 0.950 & 0.950 & 1.012 & 0.961 & 103 \\
\hline 2 & Oman & Asia & 226 & 0.529 & 1.000 & 0.965 & 0.965 & 1.100 & 1.061 & 19 & 1.008 & 1.024 & 1.032 & 1.093 & 1.128 & 161 \\
\hline 2 & Kuwait & Asia & 111 & 0.870 & 1.000 & 0.975 & 0.975 & 1.088 & 1.060 & 20 & 1.026 & 1.112 & 1.141 & 1.028 & 1.173 & 64 \\
\hline 2 & Mauritania & Africa & 351 & 0.582 & 1.000 & 0.975 & 0.975 & 1.087 & 1.060 & 21 & 1.000 & 0.910 & 0.910 & 1.097 & 0.998 & 129 \\
\hline 2 & Réunion & Africa & 145 & 0.530 & 1.000 & 0.966 & 0.966 & 1.096 & 1.060 & 22 & 1.007 & 0.991 & 0.997 & 1.090 & 1.087 & 156 \\
\hline 2 & Swaziland & Africa & 257 & 0.440 & 1.000 & 0.973 & 0.973 & 1.087 & 1.057 & 23 & 1.000 & 0.950 & 0.950 & 1.211 & 1.151 & 87 \\
\hline 2 & Timor-Leste & Asia & 108 & 0.468 & 1.000 & 0.970 & 0.970 & 1.087 & 1.055 & 24 & 1.000 & 0.955 & 0.955 & 1.207 & 1.153 & 84 \\
\hline 2 & Puerto Rico & A. Carrabin & 386 & 0.513 & 1.000 & 0.964 & 0.964 & 1.092 & 1.053 & 25 & 1.007 & 0.987 & 0.994 & 1.098 & 1.091 & 128 \\
\hline 3 & Albania & Europe & 809 & 1.000 & 1.000 & 1.000 & 1.000 & 1.229 & 1.229 & 1 & 1.067 & 0.967 & 1.032 & 1.133 & 1.169 & 71 \\
\hline 3 & Burundi & Africa & 959 & 0.955 & 1.000 & 0.999 & 0.999 & 1.209 & 1.208 & 2 & 1.067 & 0.996 & 1.063 & 1.066 & 1.133 & 98 \\
\hline 3 & $\begin{array}{c}\text { Central Africaican } \\
\text { Renuıhlir. }\end{array}$ & Africa & 631 & 0.922 & 1.000 & 0.998 & 0.998 & 1.197 & 1.194 & 3 & 1.068 & 1.101 & 1.176 & 1.109 & 1.304 & 8 \\
\hline 3 & El Salvador & C. America & 925 & 0.855 & 1.000 & 1.004 & 1.004 & 1.174 & 1.178 & 4 & 1.041 & 0.994 & 1.035 & 1.219 & 1.262 & 13 \\
\hline 3 & Haiti & A. Carrabin & 942 & 0.909 & 1.000 & 0.995 & 0.995 & 1.156 & 1.150 & 5 & 1.026 & 1.077 & 1.105 & 0.921 & 1.017 & 148 \\
\hline 3 & Jamaica & A. Carrabin & 504 & 0.912 & 1.000 & 0.996 & 0.996 & 1.150 & 1.145 & 6 & 1.026 & 1.105 & 1.134 & 0.994 & 1.128 & 104 \\
\hline 3 & Jordan & Asia & 638 & 0.904 & 1.000 & 0.997 & 0.997 & 1.143 & 1.140 & 7 & 1.026 & 1.108 & 1.136 & 0.990 & 1.125 & 110 \\
\hline 3 & $\begin{array}{l}\text { Lao People's Dem- } \\
\text { ncratic Renı ıhlir. }\end{array}$ & Asia & 850 & 0.873 & 1.000 & 0.992 & 0.992 & 1.136 & 1.127 & 8 & 1.026 & 1.128 & 1.157 & 1.044 & 1.208 & 36 \\
\hline 3 & Zambia & Africa & 794 & 0.679 & 1.000 & 0.992 & 0.992 & 1.086 & 1.077 & 9 & 1.000 & 0.922 & 0.922 & 1.163 & 1.073 & 134 \\
\hline 3 & Mongolia & Asia & 820 & 0.821 & 1.000 & 0.996 & 0.996 & 1.079 & 1.075 & 10 & 1.000 & 0.903 & 0.903 & 1.111 & 1.002 & 154 \\
\hline 3 & Libya & Africa & 893 & 0.925 & 1.000 & 0.992 & 0.992 & 1.082 & 1.073 & 11 & 1.000 & 0.942 & 0.942 & 1.005 & 0.947 & 162 \\
\hline 3 & Nicaragua & C. America & 848 & 0.843 & 1.000 & 0.995 & 0.995 & 1.072 & 1.067 & 12 & 1.004 & 0.903 & 0.906 & 1.129 & 1.023 & 142 \\
\hline 3 & Panama & C. America & 797 & 1.000 & 1.000 & 0.984 & 0.984 & 1.075 & 1.057 & 13 & 1.006 & 0.979 & 0.985 & 1.171 & 1.154 & 81 \\
\hline 3 & Yemen & Asia & 929 & 0.738 & 1.000 & 0.990 & 0.990 & 1.054 & 1.044 & 14 & 1.000 & 0.924 & 0.924 & 1.182 & 1.092 & 127 \\
\hline 3 & Togo & Africa & 548 & 0.794 & 1.000 & 0.989 & 0.989 & 1.014 & 1.002 & 15 & 1.000 & 0.952 & 0.952 & 1.225 & 1.166 & 72 \\
\hline 3 & Senegal & Africa & 947 & 0.901 & 1.000 & 0.986 & 0.986 & 0.965 & 0.952 & 16 & 1.007 & 0.995 & 1.002 & 1.174 & 1.176 & 60 \\
\hline 4 & Cambodia & Asia & 1507 & 0.964 & 1.000 & 1.001 & 1.001 & 1.225 & 1.226 & 1 & 1.067 & 0.996 & 1.063 & 1.062 & 1.129 & 102 \\
\hline 4 & Angola & Africa & 1203 & 1.000 & 1.000 & 1.000 & 1.000 & 1.200 & 1.200 & 2 & 1.067 & 0.983 & 1.049 & 1.073 & 1.125 & 111 \\
\hline 4 & Benin & Africa & 1188 & 1.000 & 1.000 & 1.000 & 1.000 & 1.163 & 1.162 & 3 & 1.067 & 0.993 & 1.060 & 1.162 & 1.231 & 29 \\
\hline 4 & Chad & Africa & 1005 & 0.953 & 1.000 & 0.996 & 0.996 & 1.164 & 1.159 & 4 & 1.068 & 1.086 & 1.160 & 1.114 & 1.292 & 9 \\
\hline 4 & $\begin{array}{c}\text { Bolivia (Plurination- } \\
\text { al State nf) }\end{array}$ & S. America & 1970 & 0.984 & 1.000 & 0.999 & 0.999 & 1.145 & 1.143 & 5 & 1.067 & 0.994 & 1.061 & 1.164 & 1.235 & 25 \\
\hline 4 & Costa Rica & C. America & 1815 & 0.918 & 1.000 & 0.995 & 0.995 & 1.136 & 1.130 & 6 & 1.041 & 0.985 & 1.025 & 1.221 & 1.252 & 17 \\
\hline 4 & Burkina Faso & Africa & 1329 & 0.975 & 1.000 & 0.997 & 0.997 & 1.127 & 1.124 & 7 & 1.067 & 0.996 & 1.063 & 1.089 & 1.158 & 77 \\
\hline 4 & Dominican Republic & A. Carrabin & 1858 & 0.911 & 1.000 & 0.998 & 0.998 & 1.125 & 1.122 & 8 & 1.041 & 0.993 & 1.034 & 1.215 & 1.256 & 15 \\
\hline 4 & Guinea & Africa & 1239 & 0.909 & 1.000 & 0.991 & 0.991 & 1.121 & 1.111 & 9 & 1.026 & 1.063 & 1.090 & 0.977 & 1.065 & 136 \\
\hline 4 & Honduras & C. America & 1311 & 0.913 & 1.000 & 0.989 & 0.989 & 1.112 & 1.100 & 10 & 1.026 & 1.081 & 1.109 & 0.924 & 1.024 & 140 \\
\hline 4 & Lebanon & Asia & 1084 & 0.915 & 1.000 & 0.988 & 0.988 & 1.108 & 1.094 & 11 & 1.026 & 1.101 & 1.130 & 1.058 & 1.195 & 46 \\
\hline 4 & Malawi & Africa & 1349 & 0.878 & 1.000 & 0.989 & 0.989 & 1.104 & 1.091 & 12 & 1.000 & 0.931 & 0.931 & 0.994 & 0.926 & 165 \\
\hline 4 & Zimbabwe & Africa & 1571 & 0.649 & 1.000 & 1.005 & 1.005 & 1.070 & 1.076 & 13 & 1.000 & 0.922 & 0.922 & 1.161 & 1.069 & 135 \\
\hline 4 & Norway & Europe & 1461 & 0.761 & 1.000 & 0.997 & 0.997 & 1.049 & 1.047 & 14 & 1.006 & 0.903 & 0.908 & 1.086 & 0.986 & 160 \\
\hline 4 & Somalia & Africa & 1430 & 0.621 & 1.000 & 1.007 & 1.007 & 1.038 & 1.045 & 15 & 1.007 & 0.996 & 1.003 & 1.199 & 1.203 & 8 \\
\hline 4 & Niger & Africa & 1478 & 0.740 & 1.000 & 0.999 & 0.999 & 1.027 & 1.026 & 16 & 1.004 & 0.902 & 0.906 & 1.101 & 0.997 & 158 \\
\hline 4 & Rwanda & Africa & 1140 & 0.711 & 1.000 & 1.004 & 1.004 & 1.005 & 1.008 & 17 & 1.007 & 0.992 & 0.999 & 1.097 & 1.096 & 126 \\
\hline 4 & Mozambique & Africa & 1417 & 0.830 & 1.000 & 0.987 & 0.987 & 1.001 & 0.988 & 18 & 1.000 & 0.901 & 0.901 & 1.122 & 1.011 & 150 \\
\hline 4 & Papua New Guinea & Oceania & 1877 & 0.715 & 1.000 & 0.998 & 0.998 & 0.978 & 0.975 & 19 & 1.007 & 0.950 & 0.957 & 1.211 & 1.159 & 76 \\
\hline 4 & Mali & Africa & 1739 & 0.835 & 1.000 & 0.987 & 0.987 & 0.960 & 0.948 & 20 & 1.000 & 0.920 & 0.920 & 1.100 & 1.012 & 149 \\
\hline 5 & Afghanistan & Asia & 2471 & 1.000 & 1.000 & 1.000 & 1.000 & 1.334 & 1.334 & 1 & 1.067 & 0.950 & 1.014 & 1.162 & 1.178 & 56 \\
\hline 5 & Algeria & Africa & 3485 & 0.972 & 1.000 & 0.997 & 0.997 & 1.277 & 1.273 & 2 & 1.067 & 0.975 & 1.041 & 1.126 & 1.172 & 65 \\
\hline 5 & Cameroon & Africa & 2584 & 0.954 & 1.000 & 0.995 & 0.995 & 1.236 & 1.230 & 3 & 1.067 & 0.996 & 1.063 & 1.057 & 1.124 & 113 \\
\hline 5 & Cuba & A. Carrabin & 3694 & 0.943 & 1.000 & 0.998 & 0.998 & 1.209 & 1.207 & 4 & 1.041 & 0.988 & 1.028 & 1.209 & 1.243 & 23 \\
\hline 5 & $\begin{array}{l}\text { Democratic Peo- } \\
\text { nle'c Renıllir of }\end{array}$ & Asia & 3562 & 0.942 & 1.000 & 0.998 & 0.998 & 1.188 & 1.187 & 5 & 1.041 & 0.990 & 1.031 & 1.270 & 1.309 & 7 \\
\hline 5 & $\begin{array}{l}\text { Democratic Repub- } \\
\text { lir. nf the S.nnnn }\end{array}$ & Africa & 70 & 0.964 & 1 & 0 & 0 & 5 & 1.170 & 6 & 1 & 1 & 31 & 52 & 91 & 0 \\
\hline 5 & Ghana & Africa & 3296 & 0.972 & 1.000 & 0.992 & 0.992 & 1.172 & 1.162 & 7 & 1.042 & 1.130 & 1.177 & 1.114 & 1.311 & 6 \\
\hline 5 & Finland & Europe & 2245 & 1.000 & 1.000 & 0.994 & 0.994 & 1.161 & 1.155 & 8 & 1.041 & 0.995 & 1.036 & 1.163 & 1.205 & 37 \\
\hline
\end{tabular}


Table 14. Cont

\begin{tabular}{|c|c|c|c|c|c|c|c|c|c|c|c|c|c|c|c|c|}
\hline \multirow{2}{*}{$\mathrm{G}$} & \multirow{2}{*}{ Duntries } & \multirow{2}{*}{ egions } & \multirow{2}{*}{$\frac{\mathrm{Q}}{\mathrm{IS} \text { million }}$} & \multicolumn{6}{|c|}{ Estimation for countries in each groups } & \multirow{2}{*}{$\begin{array}{l}0 \\
1\end{array}$} & \multicolumn{5}{|c|}{ Estimation for countries as one groups } & \multirow{2}{*}{$\mathrm{O} 2$} \\
\hline & & & & Teff. & $\begin{array}{l}\text { Teff.c } \\
h\end{array}$ & Seff.ch. & Teff.ch & Tch. & TFPch & & PTeff.ch & Seff.ch & Teff.ch & Tch. & TFPch. & \\
\hline 5 & Guatemala & C. America & 2374 & 0.984 & 1.000 & 0.991 & 0.991 & 1.155 & 1.145 & 9 & 1.026 & 1.056 & 1.084 & 0.991 & 1.074 & 133 \\
\hline 5 & Iraq & Asia & 2632 & 0.992 & 1.000 & 0.987 & 0.987 & 1.145 & 1.131 & 10 & 1.026 & 1.097 & 1.125 & 1.005 & 1.131 & 99 \\
\hline 5 & Israel & Asia & 2071 & 0.925 & 1.000 & 0.987 & 0.987 & 1.142 & 1.127 & 11 & 1.026 & 1.101 & 1.130 & 0.998 & 1.128 & 105 \\
\hline 5 & Madagascar & Africa & 2569 & 0.903 & 1.000 & 0.989 & 0.989 & 1.131 & 1.118 & 12 & 1.000 & 0.937 & 0.937 & 1.008 & 0.944 & 163 \\
\hline 5 & Paraguay & America & 2684 & 0.866 & 1.000 & 0.991 & 0.991 & 1.122 & 1.112 & 13 & 1.007 & 0.967 & 0.974 & 1.209 & 1.177 & 58 \\
\hline 5 & Nepal & Asia & 3189 & 0.931 & 1.000 & 0.987 & 0.987 & 1.126 & 1.111 & 14 & 1.001 & 0.898 & 0.899 & 1.134 & 1.019 & 145 \\
\hline 5 & Uruguay & America & 2537 & 0.755 & 1.000 & 0.989 & 0.989 & 1.092 & 1.080 & 15 & 1.000 & 0.927 & 0.927 & 1.244 & 1.154 & 82 \\
\hline 5 & Tunisia & Africa & 2536 & 0.633 & 1.000 & 0.994 & 0.994 & 1.074 & 1.067 & 16 & 1.000 & 0.940 & 0.940 & 1.189 & 1.118 & 118 \\
\hline 5 & Switzerland & urope & 2886 & 0.627 & 1.000 & 0.996 & 0.996 & 1.050 & 1.047 & 17 & 1.000 & .961 & 0.961 & 1.222 & 1.175 & 32 \\
\hline 5 & Sweden & Europe & 3376 & 0.669 & 1.000 & 0.997 & 0.997 & 1.023 & 1.020 & 18 & 1.000 & 0.958 & 0.958 & 1.202 & 1.152 & 85 \\
\hline 5 & Sri Lanka & Asia & 2201 & 0.722 & 1.000 & 1.000 & 1.000 & 0.985 & 0.985 & 19 & 1.007 & 1.128 & 1.136 & 1.247 & 1.416 & 1 \\
\hline 5 & Saudi Arabia & Asia & 2362 & 0.773 & 1.000 & 1.000 & 1.000 & 0.942 & 0.942 & 20 & 1.007 & 0.995 & 1.001 & 1.177 & 1.178 & 57 \\
\hline 5 & Portugal & Europe & 3929 & 0.809 & 1.000 & 0.999 & 0.999 & 0.894 & 0.894 & 21 & 1.0 & 986 & 0.992 & 1.110 & 1.101 & 125 \\
\hline 6 & Austria & Europe & 4501 & 1.000 & 1.000 & 1.000 & 1.000 & 1.235 & 1.235 & 1 & 1.067 & 0.990 & 1.056 & 1.127 & 1.190 & 48 \\
\hline 6 & Bulgaria & urope & 4463 & 1.000 & 1.000 & 0.999 & 0.999 & 1.210 & 1.208 & 2 & 1.067 & .995 & 1.062 & 1.079 & 1.146 & 90 \\
\hline 6 & Chile & America & 5199 & 0.891 & 1.000 & 1.003 & 1.003 & 1.189 & 1.193 & 3 & 1.041 & 0.950 & 0.989 & 1.123 & 1.110 & 121 \\
\hline 6 & Côte d'Ivoire & Africa & 4310 & 0.950 & 1.000 & 1.001 & 1.001 & 1.171 & 1.173 & 4 & 1.041 & 0.987 & 1.027 & 1.219 & 1.252 & 18 \\
\hline 6 & Denmark & Europe & 6347 & 0.919 & 1.000 & 1.000 & 1.000 & 1.131 & 1.131 & 5 & 1.041 & 0.992 & 1.032 & 1.228 & 1.267 & 12 \\
\hline 6 & Ecua & S. America & 4198 & 0.954 & 1.000 & 0.997 & 0.997 & 1.123 & 1.120 & 6 & 1.041 & 0.994 & 1.034 & 1.214 & 1.255 & 16 \\
\hline 6 & - & . & . & . & 1. & ( & s & 1 & 5 & 7 & 1.026 & 4 & 2 & 0.976 & 1.08 & 130 \\
\hline 6 & Ireland & Europe & 4412 & 0.960 & 1.000 & 0.995 & 0.995 & 1.107 & 1.101 & 8 & 1.026 & 1.099 & 1.128 & 1.001 & 1.128 & 106 \\
\hline 6 & Kenya & Africa & 4214 & 0.915 & 1.000 & 0.995 & 0.995 & 1.086 & 1.080 & 9 & 1.026 & 1.110 & 1.138 & 1.021 & 1.162 & 74 \\
\hline 6 & Sudan (former) & Africa & 5890 & 0.948 & 1.000 & 0.995 & 0.995 & 1.082 & 1.076 & 10 & 1.007 & 1.101 & 1.109 & 1.246 & 1.381 & 2 \\
\hline 6 & Morocco & Africa & 5134 & 0.958 & 1.000 & 0.992 & 0.992 & 1.080 & 1.071 & 11 & 1.000 & 0.902 & 0.902 & 1.116 & 1.007 & 34 \\
\hline 6 & Peru & S. America & 4579 & 0.948 & 1.000 & 0.993 & 0.993 & 1.079 & 1.071 & 12 & 1.007 & 0.975 & 0.982 & 1.237 & 1.214 & 88 \\
\hline 6 & Venezuela (B & Americ & 4694 & 0.961 & 1.000 & 0.98 & 0.987 & 1.086 & 1.071 & 13 & 1.000 & 0.925 & 0.925 & 1.242 & 1.149 & 152 \\
\hline 6 & U & Africa & 4 & 0.929 & 1 & 0.991 & 0.991 & 1 & 9 & 14 & 1.000 & 8 & 38 & 25 & & 9 \\
\hline 6 & Uganda & Africa & 4197 & 0.968 & 1.000 & 0.992 & 0.992 & 1.019 & 1.010 & 15 & 1.000 & 0.937 & 0.937 & 1.187 & 1.113 & 120 \\
\hline 6 & $\begin{array}{c}\text { Syrian Arab Repub- } \\
\text { lir. }\end{array}$ & Asia & 4699 & 0.963 & 1.000 & 0.995 & 0.995 & 0.967 & 0.962 & 16 & 1.000 & 0.958 & 0.958 & 1.221 & 1.170 & 68 \\
\hline 7 & Viet Nam & Asia & 14381 & 0.776 & 1.000 & 0.989 & 0.989 & 1.150 & 1.137 & 1 & 1.000 & 0.925 & 0.925 & 1.245 & 1.152 & 86 \\
\hline 7 & South Africaica & Africa & 9459 & 0.785 & 1.000 & 0.990 & 0.990 & 1.118 & 1.106 & 2 & 1.007 & 0.996 & 1.003 & 1.220 & 1.224 & 30 \\
\hline 7 & Romania & Europe & 10648 & 0.803 & 1.000 & 0 & 0.990 & 1.101 & 1.090 & 3 & 1.007 & 0.992 & 0.998 & 1.126 & 1.124 & 114 \\
\hline 7 & Republic of Ko & Asia & 8612 & 0.812 & 1.00 & 0 & 91 & 1.086 & 1.077 & 4 & 1.0 & 0.990 & 0.997 & 1.089 & 1.085 & 131 \\
\hline 7 & ilippines & sia & 13914 & 0.886 & 1. & 0.99 & 0.990 & 1.079 & 1.067 & 5 & 1.007 & .980 & 0.986 & 1.213 & 1.196 & 14 \\
\hline 7 & New Zealand & Oceania & 8004 & 0.891 & 1.000 & 0.991 & 0.991 & 1.071 & 1.061 & 6 & 1.003 & 0.902 & 0.905 & 1.133 & 1.025 & 139 \\
\hline 7 & Netherlands & Europe & 12206 & 0.884 & 1.000 & 0.993 & 0.993 & 1.058 & 1.051 & 7 & 1.004 & 0.908 & 0.912 & 1.129 & 1.030 & 138 \\
\hline 7 & Myanmar & Asia & 9101 & 0.897 & 1.000 & 0.994 & 0.994 & 1.051 & 1.045 & 8 & 1.000 & 0.900 & 0.900 & 1.132 & 1.018 & 147 \\
\hline 7 & Malaysia & Asia & 8501 & 0.938 & 1.000 & 0 & 0.994 & 1.049 & 1.043 & 9 & 1.000 & 0.926 & 0.926 & 1.010 & 0.935 & 164 \\
\hline 7 & Greece & urope & 8382 & 0012 & 1.000 & 0 & 0.996 & 1.037 & 1.033 & 10 & $10 ?$ & 0.998 & 1.024 & 1.105 & 1.131 & 100 \\
\hline 7 & Egypt & Africa & 13243 & 0.965 & 1.000 & 0.997 & 0.997 & 1.012 & 1.009 & 11 & 1.041 & 0.994 & 1.034 & 1.209 & 1.251 & 20 \\
\hline 7 & Colombia & Ameri & 10087 & 1.000 & 1.000 & 0.998 & 0.998 & 0.996 & 0.994 & 12 & 1.041 & 0.975 & 1.014 & 1.180 & 1.197 & 43 \\
\hline 7 & Bangladesh & Asia & 12494 & 1.000 & 1.000 & 1.000 & 1.000 & 0.978 & 0.978 & 13 & 1.067 & 0.992 & 1.058 & 1.165 & 1.233 & 27 \\
\hline 8 & Argentina & S. America & 28183 & 1.000 & 1.000 & 1.000 & 1.000 & 1.204 & 1.204 & 1 & 1.067 & 0.987 & 1.054 & 1.122 & 1.182 & 51 \\
\hline 8 & Australia & manis & 20818 & 0.933 & 1.000 & 1.003 & 1.003 & 1.154 & 1.157 & 2 & 1.06 & 0.989 & 1.055 & 1.120 & 1.182 & 52 \\
\hline 8 & razil & America & 76130 & 0.910 & 1.000 & 1.000 & 1.000 & 1.117 & 1.117 & 3 & 1.067 & 0.994 & 1.061 & 1.147 & 1.217 & 33 \\
\hline 8 & Canada & N. America & 21937 & 0.936 & 1.000 & 0.998 & 0.998 & 1.100 & 1.098 & 4 & 1.067 & 0.996 & 1.063 & 1.049 & 1.115 & 119 \\
\hline 8 & $\begin{array}{l}\text { United States } \\
\text { Americ:a }\end{array}$ & N. America & 191174 & 0.649 & 1.000 & 1.002 & 1.002 & 1.095 & 1.097 & 5 & 1.000 & 0.932 & 0.932 & 1.224 & 1.140 & 95 \\
\hline 8 & China & Asia & 292930 & 0.905 & 1.000 & 0.999 & 0.999 & 1.089 & 1.088 & 6 & 1.0 & 0.967 & 1.006 & 1.135 & 1.142 & 33 \\
\hline 8 & United Kingdom & Europe & 18516 & 0.64 & 1.000 & 1.00 & 1.003 & 1.076 & 1.079 & 7 & 1.000 & .939 & 99 & 1.215 & 1.141 & 4 \\
\hline 8 & 作 & rope & 42525 & 0.895 & 1.000 & 0.997 & 0.997 & 1.079 & 1.075 & 8 & 1.041 & 0.995 & 1.036 & 1.160 & 1.201 & 39 \\
\hline 0 & Germany & Europe & 35616 & 0.881 & 1.000 & 1.000 & 1.000 & 1.072 & 1.073 & 9 & 1.042 & 1.129 & 1.176 & 1.127 & 1.325 & 5 \\
\hline 8 & Turkey & Asia & 27639 & 0.672 & 1.000 & 1.002 & 1.002 & 1.061 & 1.062 & 10 & 1.000 & 0.939 & 0.939 & 1.211 & 1.137 & 97 \\
\hline
\end{tabular}


Table 14. Cont

\begin{tabular}{|c|c|c|c|c|c|c|c|c|c|c|c|c|c|c|c|c|}
\hline \multirow{2}{*}{ G } & \multirow{2}{*}{ Countries } & \multirow{2}{*}{ Regions } & Q & \multicolumn{6}{|c|}{ Estimation for countries in each groups } & \multirow{2}{*}{$\begin{array}{l}0 \\
1\end{array}$} & \multicolumn{5}{|c|}{ Estimation for countries as one groups } & \multirow{2}{*}{$\mathrm{O} 2$} \\
\hline & & & IS million & Teff. & $\begin{array}{c}\text { PTeff.c } \\
h\end{array}$ & Seff.ch. & Teff.ch & Tch. & TFPch & & PTeff.ch & Seff.ch & Teff.ch & Tch. & TFPch. & \\
\hline 8 & Indonesia & Asia & 33829 & 0.889 & 1.000 & 0.998 & 0.998 & 1.057 & 1.055 & 11 & 1.026 & 1.092 & 1.120 & 1.004 & 1.125 & 112 \\
\hline 8 & Mexico & C. America & 25934 & 0.840 & 1.000 & 0.996 & 0.996 & 1.060 & 1.055 & 12 & 1.000 & 0.905 & 0.905 & 1.112 & 1.006 & 153 \\
\hline 8 & Nigeria & Africa & 21555 & 0.846 & 1.000 & 0.994 & 0.994 & 1.060 & 1.055 & 13 & 1.006 & 0.905 & 0.910 & 1.095 & 0.997 & 159 \\
\hline 8 & Japan & Asia & 20019 & 0.847 & 1.000 & 0.996 & 0.996 & 1.057 & 1.053 & 14 & 1.026 & 1.106 & 1.134 & 0.991 & 1.124 & 115 \\
\hline 8 & Italy & Europe & 32429 & 0.857 & 1.000 & 0.996 & 0.996 & 1.055 & 1.050 & 15 & 1.026 & 1.103 & 1.132 & 0.996 & 1.127 & 108 \\
\hline 8 & $\begin{array}{l}\text { Iran (Islamic Repub- } \\
\text { lic. } n f \text { ) }\end{array}$ & Asia & 16100 & 0.967 & 1.000 & 0.992 & 0.992 & 1.051 & 1.043 & 16 & 1.026 & 1.095 & 1.123 & 0.999 & 1.122 & 116 \\
\hline 8 & Thailand & Asia & 21093 & 0.720 & 1.000 & 0.998 & 0.998 & 1.043 & 1.042 & 17 & 1.000 & 0.954 & 0.954 & 1.195 & 1.139 & 96 \\
\hline 8 & India & Asia & 143688 & 0.920 & 1.000 & 0.994 & 0.994 & 1.047 & 1.040 & 18 & 1.026 & 1.090 & 1.118 & 1.012 & 1.131 & 101 \\
\hline 8 & Spain & Europe & 27696 & 0.740 & 1.000 & 1.000 & 1.000 & 1.013 & 1.013 & 19 & 1.007 & 0.996 & 1.003 & 1.232 & 1.235 & 26 \\
\hline 8 & Poland & Europe & 21608 & 0.754 & 1.000 & 1.000 & 1.000 & 0.981 & 0.980 & 20 & 1.007 & 0.983 & 0.990 & 1.118 & 1.107 & 123 \\
\hline 8 & Pakistan & Asia & 23896 & 0.789 & 1.000 & 0.998 & 0.998 & 0.930 & 0.928 & 21 & 1.007 & 0.997 & 1.004 & 1.172 & 1.176 & 61 \\
\hline \multicolumn{4}{|c|}{ All overall mean } & 0.817 & 1.001 & 0.991 & 0.992 & 1.100 & 1.091 & & 1.024 & 0.991 & 1.014 & 1.127 & 1.143 & \\
\hline
\end{tabular}

Teff.: technical efficiency, Teff.ch.: technical efficiency change, Tch.:, technical change,PTeff.ch. pure technical efficiency change, Seff.ch. scale efficiency change, TFPch.: total factor productivity change, column (01) of table (14) shows the rank of countries in each group in descending order of the magnitude of the total factor productivity changes. column (02) of table (14) shows the rank of countries in descending order of the magnitude of the total factor productivity changes depend on Estimation for countries as one group

Source: results of Data Envelopment Analysis (DEA)

Table (14) shows that the means technical efficiency change, technical change, pure technical efficiency change scale efficiency change, and TFP change for each country in each group during 1980-2007. For instance, Sao Tome, Seychelles, and Samoa posted the highest TFP change on group (1) of $18.3,18$ and $17.6 \%$, due to technical change which posted of $16.1,16.2$ and $15.2 \%$, respectively. While, the technical efficiency change for those countries are posted of $1.8,1.5$ and 2.1 $\%$, respectively during the same period 1980-2007.

Table (14) also shows Botswana, Congo, and Bhutan posted the highest TFP change on group (2) of $12.1,11.7$ and $11.2 \%$ due to technical change 12, 11.9 and $11.2 \%$, respectively. For countries on group (3), Albania, Burundi, and Central African Republic posted the highest TFP change of $22.9,20.8$ and $19.4 \%$, due to technical change 22.9, 20.9 and 19.7\%, respectively. Cambodia, Angola, and Benin achieved the highest TFP change on group (4). Those countries posted of 22.6, 20 and $16.2 \%$ due to technical change 22.5, 20 and 16.3\% respectively. Also, Afghanistan, Algeria, and Cameroon posted the highest TFP change on group (5) of 33.4, 27.3 and 23 $\%$ due to technical change 33.4,27.7and $23.6 \%$, respectively. While, Austria, Bulgaria, and Chile posted the highest TFP change on group (6) of 23.5, 20.8 and 19.3\%due to technical change 23.5, 21 and $18.9 \%$ respectively. Vietnam, South Africa, and Romania are posted the highest TFP change on group (7) of 13.7, 10.6 and $9 \%$ due to technical change 15, 11.8 and $10.1 \%$, respectively. Finally, Argentina, Australia, and Brazil posted the highest TFP change on group (8) of 20.4, 15.7 and
$11.7 \%$ due to technical change $20.4,15.4$ and $11.7 \%$, respectively.

\section{2- Results for all countries based on estima- tion for countries as one group.}

Table (14) shows that there are 154 countries that had positive TFP growth from 1980 to 2007, while 11 countries had TFP decline from 1980 to 2007. Also, there are 149 countries that had positive technical change and 16 countries that had decline technical change from 1980 to 2007. According to Table (14), there are 98 countries that had positive technical efficiency change and 65 countries that had a decline in technical efficiency. Also, there are only 2 countries that showed no change from 1980 to 2007. Also, Table (14) shows the means technical efficiency change, technical change, pure technical efficiency change, scale efficiency change, and TFP change for each country 1980-2007. For instance, Sri Lanka, Sudan, and Suriname posted the highest TFP change for all countries $41.6,38.1$ and $35.3 \%$ due to technical change 24.7, 24.6 and $23.7 \%$ respectively. While, the technical efficiency change for those countries are posted of $13.6,10.9$ and $9.4 \%$, respectively.

The results which depend on estimation for countries in each group are different from the results which depends on estimation for all countries as one group. For instance, the overall groups means of TFP annually growth posted of $9.1 \%$ due to $10 \%$ annually growth of technical change which depends on estimation for countries in each group (Table 6). This finding contrust with Roa et al (2005). 
Which depends on estimation for countries as one group during 1980-2007 (Table 10). The overall groups means of TFP annually growth posted of $14.3 \%$ due to $12.7 \%$ annually growth of technical change On the other hand, Table (7) show that the overall means of Asia TFP annual growth posted of $7.6 \%$ due to $8.6 \%$ annually growth of technical change, depends on estimation for countries in each group. While Table (11) show that the overall mean for Asia TFP annually growth posted of $14.1 \%$ due to $11.6 \%$ annually growth of technical change which depends on estimation for countries as one group. Table (8) shows that the overall annual means for groups of TFP growth with the estimation depends on for countries in each group posted of $16.9 \%$ during $1980-1990,7.2 \%$ during $1991-2000,12 \%$ during 2001-2007, $0.4 \%$ during $1980-2000$ and $8.8 \%$ during 1980-2007. Table (12) shows that the overall annual means for groups of TFP growth with the estimation for all countries as one group posted of $32.3 \%$ during 1980-1990, $3.7 \%$ during $1991-2000,6.6 \%$ during $2001-$ $2007,17.1 \%$ during $1980-2000$ and $14.3 \%$ during 1980-2007.

The results of the estimation of Malmquist productivity indices for countries obtained from the base of dividing these countries to consistent groups were different than the results obtained based on considering all countries as one group. The difference in these results may be due to:

1- Dividing countries based on agriculture gross production value to consistent groups in their labor and gross capital stock is different than treating these countries as one group.

2- The consistency of the countries in the labor and gross capital stock within the same group means that these countries have almost the same level of technology. However the technology levels are different when gathering all of these countries in one group.

On the other hand, the results of Malmquist productivity indices in this study are higher than in other studies, this difference maybe due to the following reasons:

1- This study estimated Malmquist productivity indices based on inputs of the capital stock and labor at aggregate level of agricultural production, while most studies used other inputs such as land, labor, fertilizers, machines and livestock (Fulginiti and Perrin, 1997; Fulginiti \& Perrin, 1998; Fulginiti \& Perrin, 1999; Fulginiti et al 2004; Galanopoulos et al 2004; Lusigi \& Thirtle, 1997; Nin-Pratt \& Yu, 2008; Nin-Pratt \& Yu, 2010; Nkamleu et al 2006;
Nkamleu et al 2008; Pfeiffer, 2003; Rao et al 2005; Rao \& Coelli, 2011; Suhariyanto \& Thirtle, 2001; Suhariyanto et al 2001a; Suhariyanto et al 2001b; Thirtle et al 1995; Yu et al 2003 and. Mugera \& Ojede, 2011 and Arnade, 1998), use land, labor and Irrigation. On the other hand, Arnade (1994) used land, Fertilizers.

2- The time period of this study is 1980-2007, while most studies estimated Malmquist productivity indices covered the periods (19601980), (1960-1999), (1961-1985), (1961-1993), (1970-2000),(1984-2003).

3- This study estimated Malmquist productivity indices for 165 countries while other studies estimated TFP change for countries between 5 and 111 countries.

For previous reasons, some result of this study is different than those of other studies. For instance, The Malmquist TFP change is less than one in many studies over 1965-2003 such as (Fulginiti \& Perrin, 1997; Fulginiti \& Perrin, 1998; Fulginiti \& Perrin, 1999; Nin-Pratt \& Yu, 2008; Nin-Pratt \& Yu, 2010; Suhariyanto \& Thirtle, 2001; Suhariyanto et al 2001a; Suhariyanto et al 2001b; Thirtle et al 1995 and Yu et al 2003). Meanwhile, the TFP change posted of $1.002,1.02$, 1.027 in the studies of Nkamleu et al (2008), Galanopoulos et al (2004) and Roa \& Coelli (2011), respectively. On the other hand, TFP change posted highest value in some studies such as Roa et al (2005) who posted TFP change of 1.117 for 111 countries, Lusigi and Thirtle (1997) posted TFP change of 1.274 for 47 countries, NinPratt and Yu' (2008) who posted TFP change of 1.6 for 72 countries, and Pfeiffer (2003) who posted of 1.3

\section{SUMMARY AND CONCLUSION}

In this study we use aggregate level data on agricultural sector during 1980-2007 based on used Data Envelopment Analysis DEA, inputs data (labor and gross capital stock) drawn from the Food and Agriculture organization of the United Nations. This study is conducted to estimate the Malmquist productivity indices for 165 countries, which are distributed over 8 regions. Also those countries divided into 8 groups based on annual average of agricultural gross value. This paper attempts to estimate the Malmquist productivity indices for countries in each group separately, and for all 165 countries as a one group. The results of 
the estimation of Malmquist productivity indices for countries obtained from the base of dividing these countries to groups were different than the results obtained based on considering all countries as a one group.

The overall mean of the TFP change in this study during posted of 1.091 due to1.10 technical change based on estimation for countries in each group, while the TFP change posted 1.143 due to technical change posted of 1.127 based on estimation for all countries as one group.

The overall groups means of TFP annually growth posted of $9.1 \%$ due to $10 \%$ annually growth of technical change which depends on estimation for countries in each group, while the overall groups means of TFP annually growth posted of $14.3 \%$ due to $12.7 \%$ annually growth of technical change which depends on estimation for countries as one group. On the other hand, this study show that the overall means of Asia TFP annual growth posted of $7.6 \%$ due to $8.6 \%$ annually growth of technical change, depends on estimation for countries in each group. The overall mean for Asia TFP annually growth posted of $14.1 \%$ due to $11.6 \%$ annually growth of technical change which depends on estimation for countries as one group.

The results of the estimation of Malmquist productivity indices for countries obtained from the base of dividing these countries to consistent groups were different than the results obtained based on conceding all countries as one group. The difference in these results may be due to dividing countries to eight groups based on agriculture gross production value, and their labor and gross capital stock. The results are deferent when we take these countries as one group. The consistency of the countries in the labor and gross capital stock within the same group means that these countries have almost the same level of technology, the technology levels are different when gathering all of these countries in one group. On the other hand, the results of Malmquist productivity indices in this study are higher than in other studies. This difference between the results in this study and other studies maybe due to the following reasons: This study estimated Malmquist productivity indices based on inputs of the capital stock and labor at aggregate level of agricultural production, while most studies used other inputs such as land, labor, Fertilizers, Machines and Livestock.also, The time period of this study is 19802007, while most studies estimated Malmquist productivity indices covered the periods (19601980), (1960-1999), (1961-1985), (1961-1993),
(1970-2000) or (1984-2003). Finally, this study estimated Malmquist productivity indices for 165 countries while other studies estimated TFP change for countries between 5 and 111 countries.

\section{REFERENCES}

Abramovitz, M. 1962. Economic Growth in the United States, American Economic Review Vol. 52, No. 4, 762-782.

Afriat,, S.N.1972. Efficiency Estimation of Production Function, International Economic Review, 13, 568-98.

Arnade, C. 1998. Using a Programming Approach to Measure International Agricultural Efficiency and Productivity, Journal of Agricultural Economics 49, 67-84.

Arnade, C.A. (1994). Using data envelopment analysis to measure international agricultural efficiency and productivity (No. 156761). United States Department of Agriculture, Economic Research Service.

Ball, V.E., Bureau, J.C., Butault, J.P. and Nehring, R. 2001. Levels of Farm Sector Productivity: An International Comparison, Journal of Productivity Analysis 15, 5-29.

Bureau, C., Fare, R. and Grosskopf, S.1995. A Comparison of Three Nonparametric Measures of Productivity Growth in European and United States Agriculture, Journal of Agricultural Economics 46, 309-326.

Capalbo, S.M. and Antle, J.M. eds. 1988. Agricultural Productivity: Measurement and Explanation (Resources for the Future: Washington, DC).

Caves, D.W., Christensen, L.R. and Diewert W.E. 1982. The economic theory of index numbers and the measurement of input, output, and productivity. Econometrica: Journal of the Econometric Society :1393-1414.

Caves, D.W., Christensen, L.R. and Diewert W.E. 1982. The Economic Theory of Index Numbers and the Measurement of Input, Output, and Productivity, Econometrica, 50: 199340.

Chavas, J. 2001. An International Analysis of Agricultural Productivity.Agricultural investment and productivity in developing countries. L. Zepeda, ed., pp. 21-38. Rome: FAO economic and social development issue No. 148.

Coelli, T.J., Rao, D.S.P. and Battese, G.E. 1998. An Introduction to Efficiency and Productivity Analysis (Kluwer Academic Publishers: Boston. 
Coelli, T.J., Estache, A., Perelman S. and Trujillo, L. 2003b. A Primer on Efficiency Measurement for Utilities and Transport Regulators World Bank Publications.

Coelli, T.J. and Rao, D.S.P. 2005. Total factor productivity growth in agriculture: a Malmquist index analysis of 93 countries, 1980-2000. Agricultural Economics 32:115-134.

Craig, B.J., Pardey, P.G. and Roseboom J. 1997. International Productivity Patterns: Accounting for Input Quality, Infrastructure, and Research. American Journal of Agricultural Economics 79, 1064-1077.

Färe, R., Grosskopf, S. and Norris, M. 1997 Productivity growth, technical progress, and efficiency change in industrialized countries: reply. The American Economic Review, 87: 1040-1044.

Fare, R., Grosskopf, S. and Lee, W.F. 1995. Productivity and Technical Change: The Case of Taiwan, Southern Illinois University (mimeo).

Fare, R., Grosskopf, S. and Lovell C.A.K. 1994. Production Frontiers. Cambridge: Cambridge University Press,1994.

Fulginiti, L.E. and Perrin R.K. 1998. Agricultural Productivity in Developing Countries, Journal of Agricultural Economics 19, 45-51.

Fulginiti, L.E. and R.K. Perrin, 1999. Have Price Policies Damaged LDC Agricultural Productivity? Contemporary Economic Policy 17, 469475.

Fulginiti, L.E. and Perrin R.K. 1997. LDC Agriculture: Nonparametric Malmquist Productivity Indexes, Journal of Development Economics $53,373-390$.

Fulginiti, L. and Perrin, R. 1993. Prices and Productivity in Agriculture, Review of Economics and Statistics 75, 471-482.

Fulginiti, L.E., Perrin R.K. and Yu B. 2004. Institutions and agricultural productivity in SubSaharan Africa. Agricultural Economics 31: 169-180.

Galanopoulos, K., Karagiannis G. and Koutroumanidis, T. 2004. "Malmquist productivity index estimates for European agriculture in the 1990s. Operational Research 4: 73-91.

Griliches, Z. 1963. The Sources of Measured Productivity Growth: United States Agriculture 1940-1960, Journal of Political Economy, Vol. 71(4), 331-346.

Hayami, Y. and Ruttan V. 1970. Agricultural Productivity Differences among Countries, American Economic Review 40, 895- 911.
Hayami, Y. and Ruttan V. 1971. Agricultural Development: An International Perspective (Johns Hopkins University Press: Baltimore.

Kawagoe, T. and Hayami Y. 1985. An Intercountry Comparison of Agricultural Production Efficiency. American Journal of Agricultural Economics: 67: 87-92.

Kawagoe, T. and Hayami Y. 1983. The Production Structure of World Agriculture: An Intercountry Cross-Section Analysis, Developing Economies 21, 189-206.

Kumar, S. 2006. A decomposition of total productivity growth: A regional analysis of Indian industrial manufacturing growth. International Journal of Productivity and Performance Management 55, 311-313

Lau, L. and Yotopoulos, P. 1989. The MetaProduction Function Approach to Technological Change in World Agriculture," Journal of Development Economics 31, 241-269.

Lusigi, A., and Thirtle, C.G. 1997. Total Factor Productivity and the Effects of $R$ \& $D$ in Africaican Agriculture. Journal of International Development. 9, 529.

Malmquist, S. 1953. Index numbers and indifference surfaces. Trabajos de Estadistica y de Investigacion Operativa 4, 209-242.

Mugera, A.W. and A. Ojede, 2011. "Agricultural Productivity Growth in Africa: Is Efficiency Catching-up or Lagging Behind?" Australian Agricultural and Resource Economics Society.

Nadiri, M.I. 1970. Some Approaches to the Theory and Measurement of Total factor Productivity: A Survey JEL. VIII. No. A PP 1137-1177.

Nin, A., Arndt, C. and Preckel, P.V. 2003. Is Agricultural Productivity in Developing Countries Really Shrinking? New Evidence Using a Modified Nonparametric Approach, Journal of Development Economics 71, 395-415.

Nin-Pratt, A. and Yu, B. 2008. Developing Countries and Total Factor Productivity Growth in Agriculture: New Evidence Using a Malmquist Index with Constrained Implicit Shadow Prices" Paper presented at the $11^{\text {th }}$ Annual Conference on Global Economic Analysis, Helsinski, Finland, June 12-14.

Nin-Pratt, A., Yu, B. and S. Fan 2010. Comparisons of agricultural productivity growth in China and India. Journal of Productivity Analysis 33: 209-223.

Nkamleu, G.B., Nyemeck, J. and D. Sanogo. 2006. Metafrontier Analysis of Technology Gap and Productivity Difference in African 
Agriculture, University Library of Munich, Germany.

Nkamleu, G.B., Sally, K. and Zonon, A. 2008. What Account for growth in African Agriculture University Library of Munich, Germany.

Pfeiffer, L.M. 2003. Agricultural Productivity Growth in the Andean Community." American Journal of Agricultural Economics 85: 13351341.

Rao, D.S.P. and Coelli, T.J. 1998. Catch-up and Convergence in Global Agricultural Productivity, 1980-1995," CEPA Working Papers No. 4/98 (Department of Econometrics, University of New England: Armidale, p. 25.

Rao, D.S.P. and Coelli, T.J. 2011. Catch-up and Convergence in Global Agricultural Productivity, 1980-1995. Indian Economic Review 39: 123-148.

Rao, D.S.P., Coelli, T.J. and Alauddin, M. 2005. Agricultural Productivity Growth, Employment and Poverty in Developing Countries, 19702000. Geneva: International Labour Office.

Ruttan, V.W. 2002. Productivity Growth in World Agriculture: Sources and Constraints, Journal of Economic Perspectives 16, 161-184.

Ruttan, V.W. 1960. Research on the Economics of Technological Change in American Agriculture, Journal of Farm Economics.

Shepherd R.W. 1953. Cost and production function. Princeton University press, Princeton.

Shepherd R.W. 1970. Theory of cost and production function. Princeton University press, Princeton.

Solow, R.M. 1957. Technical Change and the Aggregate Production Function, Review of Economics and Statistics, 39(3), 312-320

Suhariyanto, K. 2001. Agricultural Productivity Growth in Asian Countries. Tomorrow's agricul- ture: incentives, institutions, infrastructure and innovations. Proceedings of the $24^{\text {th }}$ International Conference of Agricultural Economists, Berlin, Germany, 13-18 August 2000, Burlington VT, pp. 376-382.

Suhariyanto, K., Lusigi, A. and Thirtle, C., 2001a. Productivity Growth and Convergence in Asian and African Agriculture. Asia and Africa in Comparative Economic Perspective (Palgrave: London, pp. 258- 274.

Suhariyanto, K. and Thirtle, C. 2001b. Asian Agricultural Productivity and Convergence, Journal of Agricultural Economics 52, 96110.

Thirtle, C.G., Hadley, D. and Townsend, R. 1995. Policy-induced Innovation in Sub-Saharan African Agriculture: A Multilateral Malmquist Productivity Index Approach. Development Policy Review 13: 323-348.

Thirtle, C.G., Piesse, J., Lusigi A. and Suhariyanto, K. 2003b. Multi-Factor Agricultural Productivity, Efficiency and Convergence in Botswana, 1981-1996. Journal of Development Economics 71: 605-624.

Trueblood, M.A. and Coggins, J. 2003. Intercountry Agricultural Efficiency and Productivity: A Malmquist Index Approach, World Bank: Washington, DC, Mimeo.

Wiebe, K., Soule, M., Narrod, C. and Breneman V. 2000. Resource Quality and Agricultural Productivity: A Multi-Country Comparison (USDA: Washington, DC, mimeo.

Yu, B., Fulginiti, L.E. and Perrin, R.K. 2003. SubSaharan Africa: Methods for Examining Institutions and Agricultural Productivity. In presentation at the American Agricultural Economics Association Annual Meeting, Montreal, Canada, pp. 27-30. 